\title{
Paraben Compounds-Part I: An Overview of Their Characteristics, Detection, and Impacts
}

\author{
João Lincho, Rui C. Martins (D) and João Gomes *(D) \\ CIEPQPF-Chemical Engineering Processes and Forest Products Research Center, Department of Chemical \\ Engineering, Faculty of Sciences and Technology, University of Coimbra, Rua Sílvio Lima, Polo II, \\ 3030-790 Coimbra, Portugal; joaopedrolincho@hotmail.com (J.L.); martins@eq.uc.pt (R.C.M.) \\ * Correspondence: jgomes@eq.uc.pt; Tel.: +351-239798723; Fax: +351-239798703
}

Citation: Lincho, J.; Martins, R.C.;

Gomes, J. Paraben Compounds-Part

I: An Overview of Their

Characteristics, Detection, and

Impacts. Appl. Sci. 2021, 11, 2307.

https://doi.org/10.3390/

app11052307

Academic Editor: Bart Van

der Bruggen

Received: 5 February 2021

Accepted: 2 March 2021

Published: 5 March 2021

Publisher's Note: MDPI stays neutral with regard to jurisdictional claims in published maps and institutional affiliations.

Copyright: (C) 2021 by the authors Licensee MDPI, Basel, Switzerland. This article is an open access article distributed under the terms and conditions of the Creative Commons Attribution (CC BY) license (https:// creativecommons.org/licenses/by/ $4.0 /$ )

\begin{abstract}
Parabens are widely used in different industries as preservatives and antimicrobial compounds. The evolution of analytical techniques allowed the detection of these compounds in different sources at $\mu \mathrm{g} / \mathrm{L}$ and $\mathrm{ng} / \mathrm{L}$. Until today, parabens were already found in water sources, air, soil and even in human tissues. The impact of parabens in humans, animals and in ecosystems are a matter of discussion within the scientific community, but it is proven that parabens can act as endocrine disruptors, and some reports suggest that they are carcinogenic compounds. The presence of parabens in ecosystems is mainly related to wastewater discharges. This work gives an overview about the paraben problem, starting with their characteristics and applications. Moreover, the dangers related to their usage were addressed through the evaluation of toxicological studies over different species as well as of humans. Considering this, paraben detection in different water sources, wastewater treatment plants, humans and animals was analyzed based on literature results. A review of European legislation regarding parabens was also performed, presenting some considerations for the use of parabens.
\end{abstract}

Keywords: parabens; toxicity; European legislation; water detection; paraben applications

\section{Introduction}

Parabens or $\mathrm{p}$-Hydroxybenzoates are derivatives of p-hydroxybenzoic acid and are used in industry, particularly in pharmaceutical, cosmetics and food, due to their appealing characteristic of acting as preservatives and antimicrobial compounds $[1,2]$

The huge development of analytical techniques in recent years is leading to the possibility of detecting compounds at very low concentrations. Thus, parabens are now being detected in several media at $\mu \mathrm{g} / \mathrm{L}$ and $\mathrm{ng} / \mathrm{L}$ scales [3]. The introduction of these compounds in nature is related to the domestic and industrial effluent discharges; according to some authors, parabens are satisfactorily removed in wastewater treatments with conventional technologies [4]. However, in reality the presence of this type of emergent compound in ecosystems is enhanced, bringing negative impacts for the environment, animals and even humans [4]. In fact, parabens can act as endocrine disruptors, which can promote adverse health risks in organisms and are also related to a carcinogenic behavior $[2,5,6]$. These detections can be explained by the increase in parabens in the composition of products [7] and/or due to a low performance of wastewater treatment plants using conventional technology [8].

Parabens are biorefractory compounds and can be easily accumulated in nature [2,5]. This type of pollution can be eradicated, or at least decreased, with the use of more powerful wastewater treatments in wastewater treatment plants (WWTPs), such as advanced oxidation processes (AOPs), due to their good performance in pollutants abatement [5,9]. Parabens, other contaminants such as endocrine disruptors [4], pharmaceutical and personal care products (PPCPs) [4], pesticides [10] and others are also detected in the environment. Since their detection was only possible due to the evolution of analytical techniques 
in late 1990s, these types of compounds won the nickname of contaminants of emerging concern (CECs).

Not forgetting the environmental pollution problems, around the world about 1.1 billion people suffer from water scarcity and about 2.7 billion should experience this problem at least one month in the year [11]. To ensure the water needs of different types of life [10,12], the correct treatment and reuse of this resource is mandatory. So, even for survival reasons, the acquisition of "pollution-free water" must be ensured, and this entails the correct elimination of parabens and other contaminants present in water. In this regard, water reclamation can be possible considering new methodologies of treatment.

This work presents an overview of the characteristics that make parabens considered a unique problem for human health. In this context, the applications of these compounds and their associated dangers will be analyzed. Moreover, considering the dangers related to parabens, current legislation will be presented. As referred to above, the conventional wastewater treatments seem to be inefficient in their removal and the detection of parabens in wastewater treatment plants and water sources will be addressed.

\section{Paraben Characteristics and Applications}

Parabens are present in nature, in bacteria [13] or plants [14,15] and fruits [16] and have been synthesized and used by industries since 1920 [17]. They are esters of $p$ hydroxybenzoic acid with different alkyl (methyl, ethyl, propyl, isopropyl, butyl, isobutyl, pentyl, heptyl) or aryl (benzyl, phenyl) groups [15]. Table 1 presents a summary of some properties of a wide range of paraben compounds.

Table 1. Properties of parabens.

\begin{tabular}{|c|c|c|c|c|c|c|c|c|}
\hline Compound & $\begin{array}{c}\text { CAS } \\
\text { Number }\end{array}$ & $\begin{array}{l}\text { Molecular } \\
\text { Formula }\end{array}$ & $\begin{array}{c}\text { Molecular } \\
\text { Mass/(g/mol) }\end{array}$ & $\begin{array}{c}\text { Melting } \\
\text { Temperature } /\left({ }^{\circ} \mathrm{C}\right)\end{array}$ & $\begin{array}{c}\text { Boiling } \\
\text { Temperature } /\left({ }^{\circ} \mathrm{C}\right)\end{array}$ & $\begin{array}{l}\text { Solubility in Water } \\
\text { at } 25^{\circ} \mathrm{C} /(\mathrm{mg} / \mathrm{L})\end{array}$ & $\begin{array}{l}\text { Dissociation } \\
\text { Constant } \\
\text { (pKa) }\end{array}$ & $\begin{array}{c}\text { Octanol-Water } \\
\text { Partition (Log } \\
\left.\mathrm{K}_{\text {ow }}\right)\end{array}$ \\
\hline $\begin{array}{l}\text { Methylparaben } \\
\text { (MP) }\end{array}$ & $99-76-3$ & $\mathrm{C}_{8} \mathrm{H}_{8} \mathrm{O}_{3}$ & 152.15 & $131^{b, c}$ & $\begin{array}{l}270-280^{b} \\
275^{c}\end{array}$ & $\begin{array}{l}5981^{\mathrm{a}} \\
2500^{\mathrm{c}} \\
2000^{\mathrm{d}}\end{array}$ & $8.17^{a, b, d}$ & $\begin{array}{l}1.96^{\mathrm{a}, \mathrm{c}} \\
1.66^{\mathrm{d}}\end{array}$ \\
\hline $\begin{array}{l}\text { Ethylparaben } \\
\text { (EP) }\end{array}$ & $120-47-8$ & $\mathrm{C}_{9} \mathrm{H}_{10} \mathrm{O}_{3}$ & 166.17 & $\begin{array}{c}116-118^{b} \\
117^{c}\end{array}$ & $\begin{array}{c}297-298^{b} \\
297.5^{c}\end{array}$ & $\begin{array}{l}1894^{\mathrm{a}} \\
885^{\mathrm{c}} \\
860^{\mathrm{d}}\end{array}$ & $8.22^{a, b, d}$ & $\begin{array}{l}2.47^{\mathrm{a}, \mathrm{c}} \\
2.19^{\mathrm{d}}\end{array}$ \\
\hline $\begin{array}{l}\text { Propylparaben } \\
\text { (PP) }\end{array}$ & $94-13-3$ & $\mathrm{C}_{10} \mathrm{H}_{12} \mathrm{O}_{3}$ & 180.20 & $\begin{array}{c}96-98^{b} \\
97^{c}\end{array}$ & $285.1^{c}$ & $\begin{array}{c}529.3^{a} \\
500^{c} \\
300^{d}\end{array}$ & $8.35^{a, b, d}$ & $\begin{array}{l}3.04^{\mathrm{a}, \mathrm{c}} \\
2.71^{\mathrm{d}}\end{array}$ \\
\hline $\begin{array}{c}\text { Butylparaben } \\
\text { (BuP) }\end{array}$ & $94-26-8$ & $\mathrm{C}_{11} \mathrm{H}_{14} \mathrm{O}_{3}$ & 194.23 & $\begin{array}{c}68-69^{b} \\
68.5^{c}\end{array}$ & $300.3^{c}$ & $\begin{array}{l}159^{a} \\
207^{c} \\
150^{d}\end{array}$ & $8.37^{a, b, d}$ & $\begin{array}{l}3.57^{\mathrm{a}, \mathrm{c}} \\
3.24^{\mathrm{d}}\end{array}$ \\
\hline $\begin{array}{l}\text { Benzylparaben } \\
\text { (BeP) }\end{array}$ & $94-18-8$ & $\mathrm{C}_{14} \mathrm{H}_{12} \mathrm{O}_{3}$ & 228.24 & $110^{c}$ & 170 & $\begin{array}{c}107.80^{\mathrm{a}} \\
160^{\mathrm{c}} \\
50^{\mathrm{d}}\end{array}$ & $\begin{array}{l}8.18^{\mathrm{a}} \\
8.50^{\mathrm{c}}\end{array}$ & $\begin{array}{l}3.56^{\mathrm{a}} \\
3.27^{\mathrm{c}}\end{array}$ \\
\hline $\begin{array}{l}\text { Pentylparaben } \\
(\mathrm{PeP})\end{array}$ & $6521-29-5$ & $\mathrm{C}_{12} \mathrm{H}_{16} \mathrm{O}_{3}$ & 208.25 & n.a & n.a & $62.50^{\mathrm{a}}$ & $8.50^{\mathrm{a}}$ & $3.96^{\mathrm{a}}$ \\
\hline $\begin{array}{c}\text { Phenylparaben } \\
\text { (PhP) }\end{array}$ & $\begin{array}{c}17696-62- \\
7\end{array}$ & $\mathrm{C}_{13} \mathrm{H}_{10} \mathrm{O}_{3}$ & 214.21 & n.a & n.a & $253^{a}$ & $8.40^{a}$ & $3.21^{\mathrm{a}}$ \\
\hline
\end{tabular}

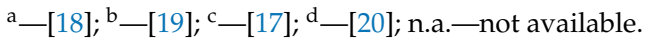

The use of these types of compounds is due to their good preservation and antimicrobial properties, but also chemical stability and low production costs, which render these compounds a good option to be used by industries $[1,20]$. Additionally, the low frequency of sensitization, their water solubility which is sufficient to produce solutions, inertness, the fact they do not change consistency or coloration of products and their nonperceptible odor or taste are properties which make parabens interesting compounds [20]. In parabens, an increase in alkyl chain length improves antimicrobial effectiveness, but the water solubility decreases, as can be seen in the Table 1 [21].

Parabens are more efficient as preservatives against fungi than bacteria, and, regarding the action against bacteria, they are more efficient against Gram-positive than Gramnegative bacteria. Their range of effectiveness may be wider when used as a combination 
of different parabens [21]. Additionally, they are effective at neutral and acid $\mathrm{pH}$, and alkaline solutions until $\mathrm{pH}=8$, where their preservative functions start to decrease [22].

Since the 1990s, the usage of parabens has increased every year, and they have already applied in various fields such as pharmaceutics, food, cosmetics and even in medicine [7]. In industry, methylparaben (MP) is known as E-218, ethylparaben (EP) as E-214, and propylparaben (PP) as E-216. Parabens received a great expansion in their usage, especially in food industries, and since 2013, almost all the types of canned or package food have parabens in their compositions [7].

Table 2 presents some products where parabens are used.

Table 2. Types of products with parabens usage.

\begin{tabular}{|c|c|c|}
\hline Type of Product & Description of Product & Reference \\
\hline Food & $\begin{array}{c}\text { Vegetable, Fats, Oils, Sugar extracts, Coffee extracts, Bottled water, Beer, Formula } \\
\text { Milk, Yogurts, Wheat flour, Bread, Cakes, Ham, Sausages, Apples, } \\
\text { Pears, Cabbages, }\end{array}$ & [7] \\
\hline Food & $\begin{array}{c}\text { Soft Drinks, Frozen dairy products, Jams, Jellies, Pickles, Sauces, Desserts, } \\
\text { Processed Fish, Flavoring Syrups }\end{array}$ & [16] \\
\hline $\begin{array}{l}\text { Cosmetics and Personal } \\
\text { Care Products }\end{array}$ & $\begin{array}{c}\text { Shampoos, Conditioners, Shower gels, Scrubs, Sunscreen, } \\
\text { Deodorants, Moisturizers }\end{array}$ & [16] \\
\hline Pharmaceuticals & $\begin{array}{c}\text { Pills, Syrups, Suppositories, Anesthetics, Eyewashes, Weight-gain drinks, } \\
\text { Injectable Solutions, Contraceptives }\end{array}$ & [22] \\
\hline $\begin{array}{l}\text { Cosmetics and Personal } \\
\text { Care Products }\end{array}$ & $\begin{array}{c}\text { Face, body and hand creams, Eye makeup products, Other makeup products, } \\
\text { Night cream and lotions, Mud packs, skin lighteners, Sachets }\end{array}$ & [21] \\
\hline Food & $\begin{array}{c}\text { Cloudberry, Yellow passion fruit juice, White wine, Botrytised wine, Bourbon } \\
\text { vanilla, Piecrusts, Icings, Toppings, Pastries, Fillings, Olives }\end{array}$ & [19] \\
\hline Food & $\begin{array}{l}\text { Beverages, Dairy products, Fats and Oils, Fish and Shellfish, Grains, Meat, Fruits, } \\
\text { Vegetables, Cereals, Eggs, Bean products, Cookies/snacks, Condiments }\end{array}$ & {$[23,24]$} \\
\hline Personal Care Products & $\begin{array}{l}\text { Body wash, Shampoo, Hair conditioner, Face cleanser, Shaving gel, Skin lotion, } \\
\text { Hair care products, Perfume, Skin toner, Deodorant, Creams, Sunscreen, Lipstick, } \\
\text { Nail polish, Baby diaper cream, Baby powder, Baby lotion and oil, Baby sunscreen }\end{array}$ & [25] \\
\hline Others & Cigarettes, Varnishes, Glue, Animal feed & [17] \\
\hline
\end{tabular}

Parabens are synthesized by a traditional method through an acid-base reaction or esterification process, using p-hydroxybenzoic acid and an alcohol (R-OH) in the presence of a catalyst such as thionyl chloride, dodeca tungstophosphoric acid or montmorillonite K10 clay. The results of this reaction are parabens and water [7]. Methylparaben and propylparaben can be produced by esterification of p-hydroxybenzoic acid and methanol for MP and n-propanol for PP, both using sulfuric acid as catalyst [21,22].

There are some alternatives for parabens such as formaldehyde, quarternium-15, imidazolidinyl urea, diazolidinyl urea and dimethyloldimethyl hydantoin or natural preservatives as thymol, cinnamaldehyde, allyl isothiocyanate, citric acid, ascorbic acid, and rosemary extract [20]. However, the use of natural preservatives brings some problems related to allergies and other health problems. Additionally, there are not enough studies to prove the efficiency and safety of these products [20]. Other preservatives are used in cosmetics, such as formic acid, propionic acid, sorbic acid, benzoic acid, salicylic acid, benzyl alcohol, 2-phenoxyethanol, sodium benzoate, triclosan, bronpol, DMDM hydantoin, methylisothiazolinone and methylchloroisothiazolinone [26].

\section{Paraben Potential Impacts}

Although parabens are efficient compounds, their wide use is under discussion among several entities and scientific community since these compounds are known as dangerous to different aquatic organisms $[5,27]$. Moreover, these compounds are related to several health 
problems, namely breast cancer [28], and problems related with reproductive systems due to the endocrine disruptive action $[29,30]$.

\subsection{Human Health Impact}

Paraben compounds can show estrogenic [31] and antiandrogenic activity [32]. As previously mentioned, these molecules have been associated with tumors, namely breast tumors [28], as well as male infertility [33]. Thus, parabens are being identified as a potential risk to human health [33]. The main sources of human exposure to parabens are the use of pharmaceutical products and cosmetics [34].

Parabens and other xenobiotic chemicals interfere with the hypothalamo-pituitarygonadal axis and behave similar to female hormones, blocking or destabilizing the normal hormonal action, negatively affecting the reproductive function of males [33]. Endocrine disruptors can interfere with endogenous hormone action, synthesis, metabolism, and transport. These compounds can also change in the normal functioning of the central nervous system, immune system, lipid homeostasis, glucose levels, thyroid function and act as epigenetic modulators causing transgenerational effects [34].

Propylparaben is nonirritating and nonsensitizing for normal skin populations, but sensitizing effects were detected in the application of medicines that contained parabens for damaged or broken skin [22]. The Ophthalmic Drug Panel of the United States Food and Drugs Administration's Bureau of Drugs considered MP and PP unsuitable for use in ophthalmic solutions preparations because they can cause eye irritation [21].

It was observed by Sabalitschka and Neufeld-Crzellitzer [35] that an ingestion of $2000 \mathrm{mg}$ of PP daily for 1 month did not cause a visible toxic effect, but another experiment by Braccesi et al. [36] using $2000 \mathrm{mg}$ of MP for an unknown period reported the same innocuousness [22]. There is not enough data that can relate the use of parabens with allergic reactions, although some people reported allergies after the ingestion of products containing parabens [22].

Elder et al. [37] reviewed several studies about human skin irritation for products with parabens at $0.1-0.8 \%$. In general, no irritation was noticed, although some cases of moderate irritation were reported. The authors summarized the results of tests with parabens in 27,230 patients with dermatitis, and for patch testing of 1-30\% parabens, only $2.2 \%$ developed sensitization. Subjects with intact skin did not had sensitization reactions to parabens [19].

Sokol et al. [38] applied MP, EP, PP and BuP at different concentrations $(5 \%, 7 \%, 10 \%$, $12 \%$ and $15 \%$ ) in propylene glycol to 50 patients for 5 days. PP up to $12 \%$ did not cause irritation, but a concentration of $15 \%$ showed some signs of irritation. For the "no effect concentration", the test was repeated in 50 humans ( 25 males and 25 females) with patches being applied for 4-8 h every day for 3 weeks, and no sensitization was reported [19].

In some countries, $15 \%$ of human couples are affected by infertility, and most of the cases are related to low sperm mobility or sperm counts [33]. In vitro studies conducted by Bao-Liang et al. (1989) [39], proved that methylparaben, ethylparaben, propylparaben and butylparaben are effective spermicides for human spermatozoan, for a spermicidal potency of $6,8,3$ and $1 \mathrm{mg} / \mathrm{mL}[19,21,23]$. A study carried out by Adoamnei et al. [40] analyzed urine, blood, and semen samples of 215 university students (18-23 years) from the Murcia region, Spain. The researchers did not find correlations between urinary parabens and reproductive hormone levels or semen parameters in young men. Nevertheless, the authors admit that more studies need to be carried out to verify and confirm this hypothesis.

Routledge et al. [41] studied the effects of MP, EP, PP and BuP on estrogenic activity, and all the parabens showed a weak estrogenic activity compared to 17-beta-estradiol. The estrogenic activity increased as the alkyl length increases. Additionally, parabens showed estrogenic activity, since it was noticed that parabens can interact with the estrogen receptor [19]. Further, Okubo et al. [42] reported estrogenic activity of EP, PP, BuP, isopropylparaben and iso-butylparaben in breast cancer cells (MCF-7 cells). The same was reported by Darbre et al. [43,44] for iso-butylparaben and benzylparaben in MCF-7 and 
ZR-75-1 cells [19]. The most common metabolite of parabens, p-hydroxybenzoic acid, was studied by Pugazhendhi et al. [45], and it was concluded that this compound can show oestrogenic activity in human cells, more specifically in human breast cancer cells, and its estrogenic behavior has already been reported using animal models. This compound is responsible for displacing [3H]oestradiol from the estrogen receptor of MCF7 cell cytosol, increasing expression of a stably transfected oestrogen-responsive reporter gene in MCF7 cells, and increasing the growth of oestrogen-dependent human breast cancer cells (MCF7 and ZR-75-1). This is relevant given the oestrogen response of this breast tumor cells, the presence of parabens in human breast tissue, and the involvement of oestrogen in the development of breast cancer.

A study carried out by McVay and Sprunt [46] showed that oral, vaginal, and rectal administration of MP and PP allowed the inhibition of candidiasis development during aureomycin (antibiotic) treatment and did not developed toxic effects [19]. Additionally, Ritzau and Swangsilpa [47] used PP for treatment of alveolitis and all the patients with PP treatment did not showed alveolitis whereas $24 \%$ of patients with placebo showed the presence of this disease [22].

Metzger et al. [48] administered about 90 and $22.5 \mathrm{mg}$ of MP and PP, respectively, and antibiotics (aureomycin) three times over three days to 17 patients. Feces samples showed that the treatment with parabens decreased the activity of yeasts compared to the control group that were only treated with the antibiotic, what means that parabens inhibit the growth of yeasts [19].

A sensitivity test for a placebo-controlled oral challenge was carried out using a mixture of $100 \mathrm{mg}$ of MP and $100 \mathrm{mg}$ of PP in 14 patients, and half of the patients reported hand eczema, one reported dermatitis of the face and another showed axillary eczema. Additionally, three had dermatitis in the lower leg, another three in the face or scalp and one had dermatitis on the forearm. After the challenge, two patients had flares of their usual dermatitis, one had flare at the paraben patch test site on the back, one had a doubtful reaction to both the paraben mixture and placebo, while the other 11 did not show any reaction to the oral challenge. The authors concluded that the oral challenge of $100 \mathrm{mg}$ of MP and PP was not a useful test procedure for patients with sensitivity to paraben mixture [21,49]. In a study carried out by George et al. [50] using 63 patients, five patients reported sensibility to a test with $3 \% \mathrm{MP}$, and in another experiment carried out by Bajaj and Chatterjee [51], about 6 of 100 patients had reactions to MP and PP, showing hypersensitivity to topical medicaments [21]. Another one carried out by Lindner et al. [52] reported severe allergic contact dermatitis in a female caused by a bondage containing MP and PP [21].

Other studies regarding the effect of parabens related to eye sensibility or inflammation, skin irritation, allergy to food antigens and other reactions, among some reports of real cases in medicine with complications using parabens in the treatment of diseases, and also some consumer reports involving paraben reactions were reviewed by Soni et al. [21].

Soni et al. [19] also reviewed several studies in which are reported adverse reactions to parabens, since most are related to skin irritation and chronic urticaria. The majority of adverse reactions related to parabens are mild and many of them involve contact sensitization caused by use of cosmetics [19]. Parabens and p-hydroxybenzoic acid are being implicated as the cause of chronic urticaria or angioedema $[19,53,54]$. Thune and Granholt [55] reported immediate reactions caused by parabens, in 5 of 37 patients with recurrent urticaria treated with $100 \mathrm{mg}$ of MP and PP each on the first day, and a tablet containing $150 \mathrm{mg}$ of each on day two [19]. Several cosmetics or medications containing parabens have already been implicated in the cause of contact sensitization, specifically dermatitis or urticaria [19].

Some members of the scientific community report the use of synthetic estrogens in the prenatal period as a cause of neurological defects, appearance of tumors or abnormalities in the immune system in the adult life [19]. A decrease in the count of male sperm has been 
linked to the use of estrogens or estrogen-like compounds in embryonic, fetal, and early postnatal development [19].

Darbre et al. [28] detected parabens at an average value of $20.6 \mathrm{ng} / \mathrm{g}$ tissue in a small number of breast tumor tissues, indicating that the presence of parabens can help to the increasing in incidence of breast cancer in women. The parabens found were MP (about $60 \%$ of total parabens), EP, n-PP, n-BuP and iso-butylparaben $[19,28]$. However, some criticisms were make about this study, since there is a lack of information and missing data such as a clear link between the parabens and cancer, the route of entry of parabens, the background of patients, lack of information of the location and type of tumor, the fact that the study only used 24 patients, the use of cosmetics, absence of control tissue, etc. [20]. Another review article provided by Darbre and Harvey, 2008 repeated the arguments that have been refuted and new data or evidence were not added [20]. A study provided by Barr et al. (2012) [56] showed that in different regions of healthy breast tissue, the concentration of different parabens was similar in different breast regions, except for PP, which was detected at higher levels in the upper outer quadrant of the breast. In 40 patients that participated in the study, seven of them had never used deodorants or other products for the underarm. This study also concludes that there are no correlations between paraben concentrations and age of patient, length of breast feeding, tumor location or tumor oestrogen receptor content $[20,56]$.

The study of McGrath [57] shows that people diagnosed with breast cancer at an early age used more antiperspirant products, and another study relative to the use of these products ran by Mirick et al. [58] did not shown difference between the control group and a group of patients diagnosed with breast cancer [33]. An article published by Castelain and Castelain [59], as other studies already mentioned, suggests that there is not enough scientific evidence that can justify the formation of breast cancer caused by parabens. However, a study by Khanna et al. [60] demonstrates in vitro that parabens can induce a transformed phenotype in human breast epithelial cells (MCF-10A), which is an approved model of carcinogenesis in vitro, and Wróbel and Gregoraszczuk et al. [61] proved that parabens cause an increase in estradiol secreting and aromatase activity, stimulating the proliferation of human breast cancer cells (MCF-7) [62].

So, although there is a lack of solid data that can prove the increase in breast cancer caused by parabens, it seems that some in vitro studies have started to verify that parabens can interact negatively with some body functions or cells, which could lead to the formation of cancer. However, solid data in vivo have not been discovered yet by the scientific community.

A study carried out by Nishihama et al. [63] on 128 female Japanese university students found a possible relation of a decrease in menstrual cycle length and high urinary paraben concentrations. This and other studies can suggest a correlation between parabens and environmental causes of human infertility.

Other studies showed that parabens can cause the inhibition of estrogen sulfation in human skin cytosolic fractions and normal human epidermal keratinocytes [64] and some genetic instabilities that have been implicated in breast cancer disease [65]. This genome instability in cells is important to genetic changes that guide tumorigenic processes $[65,66]$. Other studies such as the one reported by Decker et al. [67], showed that the association of $\mathrm{BuP}$ and decreases in thyroid T4 hormone levels in adult females, although the conclusion estimates that there is not enough statistical evidence between BuP and the decrease in thyroid hormone levels. The same was concluded by Janjua et al. [68].

A study of Ishiwatari et al. [69] showed that MP remained unmetabolized in stratum corneum (SC) of the forearm (tissue formed by the proliferation and differentiation of epidermal keratinocytes and important as protector for water loss and as a barrier for environmental stresses) after 1 month of daily applications, what means that this paraben exhibited persistence and had accumulation in the SC. It was also shown that MP influenced epidermal differentiation of the skin and decreased the proliferation of keratinocytes and changed cell morphology. 
Parabens also showed the property of being transferred from the mother to a child through transplacental passage [70]. In this study, the authors tested 50 mother-child pairs, and MP was detected in 47 of the 50 mothers and also in 47 of the 50 cord blood samples, at average levels of 20.41 and $36.54 \mathrm{ng} / \mathrm{L}$, respectively. Additionally, it was detected in both samples the presence of MP in 45 mother-child pairs, and the values were higher for children than mothers in 23 cases. Regarding BuP, only four mothers showed detectable levels of this parabens at a mean level of $40.54 \mathrm{ng} / \mathrm{L}$ and only eight cord samples were positive, with a mean of $32.5 \mathrm{ng} / \mathrm{L}$.

Jurewicz et al. [71] studied the effect of urinary parabens in male sperm quality, and the authors found statistically significant associations between urinary parabens and an increase in the percentage of sperm with abnormal morphologies, sperm with high DNA stainability, and a decrease in sperm motility and testosterone level.

Guth et al. [72] studied the presence of parabens in 382 urine samples and serum hormone concentrations of young girls, where $92 \%$ of participants had at least one paraben in the urine, and it was concluded that girls with higher urinary paraben concentrations had significantly lower serum concentrations of estradiol, luteinizing hormone (LH) and follicle stimulating hormone (FSH) but not of progesterone. The results also suggest that the exposure of parabens can alter the development and function of the endocrine system in girls.

Arya et al. [73] suggested that ethylparaben and other endocrine disruptor compounds were associated with female infertility, but the authors admit that more studies need to be carried out to prove this theory.

$\mathrm{W}$. Li et al. [74] study the relation between the prenatal exposure to parabens on neonatal thyroid function and birth weight, concluding that the prenatal exposure to parabens may affect the thyroid hormones with an increase in the levels of serum TT3. A relation between the use of parabens in this period and higher birth weights, especially in boys, was also found.

It seems that the scientific community is leading to several research studies regarding the dangers of parabens. Some arguments are made suggesting a harmful behavior of parabens due to their estrogenic behaviors and endocrine disruption capacity. Moreover, their possible association with the appearance of breast cancer can be also seen as a high health risk. However, contradictory results or arguments admitting a lack of evidence have also been presented (for example, the study of Darbre et al. [28] in which insufficient evidence was pointed as reported in Francisco and Fonseca [20], the different results reported by Castelain and Castelain [59], among other studies [20,56], the study carried out by McGrath [57], the contradictory results in the study of Mirick et al. [58], etc.). Several authors admit that more considerations and studies are needed to prove certain theories regarding the benefits or problems related to these types of compounds (for example, Nishihama et al. [63], Guth et al. [72] or Arya et al. [73] suggest more studies to prove/confirm the theories). In this way, with the global information available, in general, more reliable in vivo results are still lacking to draw solid conclusions regarding to the effect of parabens on the human health. Meanwhile, considering this and following the precautionary principle, it is advisable to minimize the release of these compounds to the environment.

\subsection{Impacts in Animals}

As already mentioned, it has been shown that parabens can act as endocrine disruptors $[29,30]$ and that ED compounds can have negative impacts on animals' reproductive systems due to their properties, causing animal feminization, abnormal formations and a decreased in the fecundity of species $[75,76]$.

Compared to $17 \beta$-estradiol, MP, EP, $\mathrm{PP}$ and BuP require much higher concentrations to obtain the same response as $17 \beta$-estradiol for yeast estrogen screen tests (in vitro study), but it was also reported that $\mathrm{BuP}$ could compete with $17 \beta$-estradiol in rats in terms of binding the estrogen receptor [34]. However, several authors have reported in in vitro 
studies that parabens show weak estrogenic effects [34] but other studies suggest that PP, $\mathrm{BuP}$ and BeP can cause adverse effects in aquatic organisms and elicit low estrogenic activity [77]. Additionally, other studies mention that the exposure of fish to low concentrations of paraben compounds can cause vitellogenin (VTG) synthesis, so with this, can cause estrogenic effects [77]. Similar conclusions were reported in studies reviewed by Bledzka et al. [34]. The effects of endocrine disruptors, namely xenoestrogens, were already noticed in alligators and fishes [78,79]. Renz et al. [79] did not find evidence of bioaccumulation of parabens in fishes, but studies carried and referred in Section 5.3 show that parabens were detected in fishes.

Soni et al. [22] reviewed studies regarding the use of propylparaben for short-term and long-term toxicity, carcinogenicity, and reproduction studies. The major studies involving PP did not show significant problems or statistically significant results for well-structured and well-defined conclusions in animals, including for carcinogenic and reproduction tests. However, some studies for products containing MP, EP, PP and BuP at $0.1-0.8 \%$ were carried out by Elder et al. [37], and some products caused slightly or minimal eye irritation in rabbits [22]. Additionally, the application of PP at $10 \%$ caused irritation when applied to rabbit skin [22]. Studies showed that rabbits fed with PP at $500 \mathrm{mg} / \mathrm{kg} / \mathrm{day}$ for 6 days did not show an any negative effects, and the first toxic effect was noticed at $3000 \mathrm{mg} / \mathrm{kg} /$ day. Regarding dogs, effects did not appear for MP or PP at $500 \mathrm{mg} / \mathrm{kg} /$ day, but toxicity appeared at $4000 \mathrm{mg} / \mathrm{kg} /$ day [22].

Some studies in rats concluded that feeding the animals PP of between 1\% and $4 \%$ caused an increase in labeling index in the prefundic area of the forestomach epithelium, and these studies opened doors for questions of the possibility of occurrence of similar problems in humans, although humans do not have a prefundic forestomachs. However, other similar studies in rats did not produce the same results [22].

Soni et al. [21] reviewed studies using methylparaben for oral, dermal, and intrathecal short-term effects, and concluded that no data or conclusions could prove toxicity effects in rats for oral or intrathecal exposition. However, a group of rabbits where dermal toxicity was studied showed moderate and well-defined erythema, slight edema, and slight desquamation, using products containing $0.2 \%$ of MP applied for 3 months daily at doses of $5.5 \mathrm{mg} / \mathrm{cm}^{2} / 8.4 \%$ body surface area $[21,37]$. For another study using the same percentage of MP and dose of 6.6 and $11 \mathrm{mg} / \mathrm{cm}^{2} / 8.4 \%$, the same occurred, and in another study of $0.2 \%$ of MP and PP in rabbits for doses of 2 and $6 \mathrm{mg} / \mathrm{cm}^{2} / 10 \%$ of area, the product caused moderate erythema, slight edema, and mild desquamation, and, occasionally, some epidermal fissures with bleeding and papuloerythema [21].

For long-term and carcinogenicity studies with methylparaben, no evidence of toxicity, abnormalities or to be carcinogenic was found in rats or dogs [21]. Additionally, contrary to what happened for PP, for MP no differences were observed in the labeling index in the prefundic area of forestomach epithelium of rats [21]. However, and although the conclusion of the test was that MP was not carcinogenic, some experiments in rats allowed an incidence of $1.5 \%$ for injection-site tumors (fibrosarcomas) compared to control [21,80]. For other studies, in tumors that appeared in rats treated with MP, only mammary fibroadenoma was higher than negative controls ( $8 \%$ and $1 \%$, respectively), and the incidence of injection-site tumors, pituitary adenomas, uterine polyps and leukemias did not had a different incidence compared to controls $[21,80]$. However, in general, the studies concluded that methylparaben is not carcinogenic for rats and mice, and for other studies in rats, mice, hamsters, and rabbits it was concluded that MP is not embryotoxic or teratogenic $[21,81,82]$.

Sokol et al. [38] tested 10\% solutions of MP and PP in rabbits and no irritation was observed in skin, but undiluted MP was tested, and $0.1 \mathrm{~mL}$ sample of ingredient caused mild irritation, and products containing $0.2-0.8 \%$ of the products showed mild or no irritation whereas a product of $0.2 \% \mathrm{MP}$ and $0.1 \% \mathrm{PP}$ showed a minimal irritation in rabbits [21]. Additionally, a hairdressing product with $0.2 \%$ of $\mathrm{MP}$ was also tested in rabbits for 21 days, and $24 \mathrm{~h}$ after each application the skin sites showed the presence of 
erythema and edema. In the beginning, the material produced light irritation but at the end of the first week this evolved to mild and moderate irritations [21,37].

Soehring et al. [83], Simonelli and Marri [84] and Elder [37] tested MP products for evidence of eye irritation. The first authors did not find evidence of eye irritation for $0.1-0.2 \%$ MP solution, the second showed that solutions of $0.2 \%$ provoked slight conjunctival hyperemia, and the third showed that the product caused slight transient irritation [21]. For rats, Becquet et al. [85] tested daily use of $0.05 \% \mathrm{MP}$ for 1 month and concluded that the rats that underwent MP treatments showed corneal and conjunctival damage, including an increase in the epithelial cell layers, the loss of goblet cells, appearance of keratinization of the most superficial cells, increase in limbal stroma and increase in the immune cell infiltration [21]. Other studies using MP, EP, $\mathrm{PP}$ and/or BuP at concentrations of $0.1-0.8 \%$ did not show evidence of eye irritation for most products, but some of them produced slight or minimal eye irritation [21,37].

Sado et al. [86] tested the effect of oral administration of EP in rats at doses of $0.2 \%$, $1 \%$ and $2 \%$ for 25 weeks. The only difference observed was that in male rats fed with $0.2 \%$ $\mathrm{EP}$, body weight increased in comparation to control group, while for $1 \%$ and $2 \%$, the male rats showed a decrease in body weight [19].

Inai et al. [87] tested the effect of iso-butylparaben at doses of $0 \%, 0.6 \%, 1.25 \%, 2.5 \%$, $5 \%$ and $10 \%$ for 6 weeks. The mice fed with the $5 \%$ and $10 \%$ doses died in the first 2 weeks, and a decrease of about $10 \%$ was noted in mice fed with the paraben at $1.25 \%$ and $2.5 \%$. No significant lesions were found in rats fed with $0.6 \%$ of iso-butylparaben, but for mice fed with $1.25 \%$ or higher dose, the existence of atrophy of the spleen, thymus and lymph nodes, multifocal degeneration, and necrosis of the hepatic parenchyma was noted [19].

Hossaini et al. [88] proved the estrogenic behaviors of MP, EP and PP, and BuP and p-hydroxybenzoic acid in a mouse uterotrophic assay of Immature B6D2F1 mice and after 4 days of oral or subcutaneous administration of parabens, an increase in uterus weight was observed. However, up to $100 \mathrm{mg} / \mathrm{kg} /$ day, none of the tested parabens caused estrogenic activity, even for $1000 \mathrm{mg} / \mathrm{kg} /$ day for ethylparaben [19]. The same was observed by Darbre et al. [43], where the subcutaneous administration of iso-butylparaben increased the uterine weight of immature mice after three doses of 1.2 or $12 \mathrm{mg}$ of parabens. Pedersen et al. [89] tested the estrogenic activity of EP, PP and BuP and their common metabolite p-hydroxybenzoic acid in sexually immature rainbow trout. The authors found out that the metabolite did not show estrogenic activity, while all the parabens showed estrogenic activity for a dose $100-300 \mathrm{mg} / \mathrm{kg} /$ day [19].

Oishi et al. [90] tested the effect of propylparaben at doses of $0 \%, 0.01 \%, 0.10 \%$ and $1 \%$ in 3-week-old rats and, after 4 weeks, their epididymides, prostates, seminal vesicles and preputial glans were analyzed. The weight of the organs was not affected, but a decrease in concentration and reserve of sperm was noticed with an increase in PP dose; this difference was significant at $0.10 \%$ or higher doses. For all groups, daily sperm production and its efficiency decreased significantly, and, serum testosterone also decreased, with special significance for the group that received the higher dose of PP. The exposure level for the observed effects is the same as the acceptable upper limit as daily intake $(10 \mathrm{mg} / \mathrm{kg}$ body weight/day) of parabens in the EU and in Japan.

Hu et al. [91] performed experiments using benzylparaben in Sprague-Dawley (SD) rats using intragastric administration. The authors found that a dose of $0.16 \mathrm{mg} / \mathrm{kg}$ body weight or higher provokes an increase in uterine weight of rats, and these results were also supported by their tests in a human estrogen receptor $\alpha(\mathrm{hER} \alpha)$-coactivator recruiting assay and in silico molecular docking analysis, which sowed estrogenic activity for $\mathrm{BeP}$ for concentrations of $1 \times 10^{-8} \mathrm{M}$ or higher.

Alam et al. [92] verified a progressive detachment and sloughing of spermatogenic cells into the lumen of the seminiferous tubules by the administration of $1000 \mathrm{mg} / \mathrm{kg}$ of butylparaben in three-week-old male rats, and the apoptosis of spermatogenic cells was higher compared to the control group, leading the authors to think that BuP can also induce the apoptosis of the spermatogenic cells. However, Hubbard et al. [93] tested an exposition 
of 0,5000, 15,000 and 40,000 ppm of BuP in Sprague-Dawley rats and did not find evidence of alterations in fertility, fecundity, pubertal attainment, or reproductive parameters in F0, F1 and F2 generations, but the authors verified that BuP caused an increase in liver weight and liver lesions which let the authors to think that the target organ of $\mathrm{BuP}$ is the liver.

Kim et al. [94] tested the effect of isopropylparaben and isobutylparaben for dermal toxicity in 28 days, for doses of 50,100, 300 or $600 \mathrm{mg} / \mathrm{kg}$ body weight/day of rats, concluding that there were no significant changes in body or organs, but these parabens caused skin damage in female rats. Additionally, the analysis of six serum hormones showed that only FSH decreased in the mixture of parabens at dose of $100 \mathrm{mg} / \mathrm{kg}$ body weight/day or higher.

Maske et al. [95] tested the presence of n-butylparaben in F0 female rats by subcutaneous application with doses of 10, 100 and $1000 \mathrm{mg} / \mathrm{kg}$ body weight/day in corn oil, from gestation (day 6) until postnatal day (day 21), and the F1 rats were analyzed at postnatal days 30,45 and 75 . The authors verified the delayed age of vaginal openings with disturbed estrus cycle in F1 female rats, reduction in fertility, problems in spermatogenesis, decrease in estradiol and progesterone, increase in testosterone levels, problems in folliculogenesis with increase in the number of primordial follicle maturation and reduced number of copora lautea, degenerated follicles in the ovaries, problems in the development of the myometrium in the uteruses of female rats and problems in levels of several estrogenic receptors. Additionally, Vo et al. [96] tested the effect of methyl-, ethyl-, propyl-, isopropyl-, butyl- and isobutylparaben in female Sprague-Dawley rats during the ingestion of 62.5, 250 and $1000 \mathrm{mg} / \mathrm{kg}$ body weight/day from postnatal day 21 to day 40 . The authors concluded that $1000 \mathrm{mg} / \mathrm{kg}$ body weight/day of MP and iso-PP delayed vaginal opening and decreased the length of the estrous cycle, and verified the weight increase in ovaries, adrenal glands, thyroid glands, liver, and kidneys. Additionally, the decrease in corpora lutea, increase in the number of cystic follicles, and thinning of the follicular epithelium was also revealed. Concentrations of estradiol and thyroxine also decrease for MP, EP, $\mathrm{PP}$, iso-PP and iso-BuP. The author concluded that a long exposition of parabens can produce suppressive effects of hormonal responsiveness and can disrupt the morphology of reproductive target tissues.

Caon and Costa [97] concluded that a mixture of MP and EP or MP and PP can cause a decrease in the permeation flux of the transdermal permeation in pig ear skin (except for $\mathrm{EP})$. The authors think that this happens due to a higher retention of these mixtures in the pig epidermis and dermis.

Dambal et al. [98] tested the effect of MP in zebrafish embryos, concluding that an increase in MP concentration of $200 \mu \mathrm{M}$ or above decreased the heart rate of 2 days postfertilization embryos, in which the control group presented 42 beats in $20 \mathrm{~s}$, while the values treated with 200,400 or $800 \mu \mathrm{M}$ had heart rate values of 36,33 and 22 beats per $20 \mathrm{~s}$. Additionally, abnormalities such as pericardial edema, bent spine and blood cell accumulation were observed, and these effects increased for higher concentrations of MP, achieving accumulation of blood cells of $5 \%, 25 \%$ and $75 \%$ for 100,200 and $400 \mu \mathrm{M}$ of MP, while pericardial edema was detected in $30 \%$ and $90 \%$ of embryos treated with MP concentrations of 200 and $400 \mu \mathrm{M}$, and the bent spine abnormality was observed in $90 \%$ of embryos treated with $400 \mu \mathrm{M}$ of MP; $100 \%$ lethality was observed in embryos exposed to MP values of $1000 \mu \mathrm{M}$ in $48 \mathrm{~h}$ after fertilization.

The results obtained by Dambal et al. [98] showed that other aquatic organisms can suffer different problems due to the presence of parabens. Lee et al. [99] tested the exposure to MP in Daphnia magna, and the acute toxicity $\mathrm{EC}_{50}$ in $48 \mathrm{~h}$ for D. magna was 36.73 and $5.70 \mathrm{mg} / \mathrm{L}$ for indoor tests using UV radiation and outdoor tests using solar radiation, respectively. The authors also concluded that after 21 days of MP exposition, the survival of D. magna decreased as the MP concentration increased (lower survival rate was observed at $10 \mathrm{mg} / \mathrm{L}$ ) and the number of young per female, number of young per brood and D. magna growth also decreased for concentrations of $3.2 \mathrm{mg} / \mathrm{L}$ of MP. The authors reports that the 
observed reduction in these parameters can affect aquatic ecosystems since invertebrates presents an important source of food for small fish in these ecosystems.

Additionally, the study reported by Terasaki et al. [100] concludes that MP, EP and PP are toxic to aquatic organisms, achieving $\mathrm{EC}_{50}$ (in $48 \mathrm{~h}$ ) values between 11 and $50 \mathrm{mg} / \mathrm{L}$ for D. magna and $\mathrm{EC}_{50}$ (in $72 \mathrm{~h}$ ) values ranged from 15 to $91 \mathrm{mg} / \mathrm{L}$ for Pseudokirchneriella subcapitata (a green algae). Terasaki et al. [100] evaluated the acute toxicity for D. magna and $V$. fischeri, reaching $\mathrm{EC}_{50}$ values of $62,32,23,30,9.2,9.8$ and $6.6 \mathrm{mg} / \mathrm{L}$ for $\mathrm{MP}, \mathrm{EP}$, $\mathrm{PP}$, iso-PP, BuP, iso-BuP and BeP, respectively, for D. magna and 5.9, 4.6, 0.26, 0.62, 1.2, 3.5 and $0.0038 \mathrm{mg} / \mathrm{L}$ for the same parabens regarding $V$. fischeri. The authors point out that these results indicate that, in general, regarding D. magna, the most tested parabens were toxic to aquatic organisms $\left(\mathrm{EC}_{50}: 1-10 \mathrm{mg} / \mathrm{L}\right)$, but other obtained results can be classified as harmful to organisms $\left(\mathrm{EC}_{50}: 10-100 \mathrm{mg} / \mathrm{L}\right)$. For $V$. fischeri, values can be classified as toxic $\left(\mathrm{EC}_{50}: 1-10 \mathrm{mg} / \mathrm{L}\right)$ and very toxic to organisms $\left(\mathrm{EC}_{50}:<1 \mathrm{mg} / \mathrm{L}\right)$. The results also show that the most toxic compounds were dichlorinated benzylparaben for D. magna and benzylparaben for $V$. fischeri. Additionally, Yamamoto et al. [101] tested the effect of parabens in Japanese medaka fish O. latipes, daphnia magna and the green algae P. subcapitata. The $\mathrm{EC}_{50}$ results were $80,52,36,48,9.5,4.0$ and $1.2 \mathrm{mg} / \mathrm{L}$ for the algae, about 34, 7.4, 2.0, 3.5, 1.9, 3.3 and $2.1 \mathrm{mg} / \mathrm{L}$ for D. magna and 63, 14, 4.9, 4.5, 3.1, 4.6 and $0.73 \mathrm{mg} / \mathrm{L}$ for the fish for MP, EP, n-PP, i-PP, n-BuP, i-BuP and BeP, respectively.

The results obtained by Dambal et al. [98], Lee et al. [99], Terasaki et al. [100] and Yamamoto et al. [101] can present a relation between the problems suffered by species and problems in aquatic ecosystems, since some of these species can present an important role in the food chain of the ecosystem.

\subsection{Toxicological Studies}

The substance toxicity is an important parameter of evaluation since it allows one to understand the effects of the referred substance in the organisms. The results are dependent on several circumstances such as types of organisms, substance concentration, route of administration, etc. For the use of compounds in several industries, their toxicity and other safety information must be known in order to produce safe products for the consumers.

Some studies revealed that the mixtures of parabens do not have synergetic effects on toxicity [22]. Additionally, low toxicity for MP was observed in laboratory animals, dogs, and rats [21].

The administration of products containing $0.2 \%$ or $0.8 \%$ by gastric intubation at doses up to $15 \mathrm{~g} / \mathrm{kg}$ of MP, EP, PP or BuP caused no deaths in rats [21,37].

Table 3 resumes toxicological studies found in the literature of parabens in different organisms.

Table 3. Toxicological studies of parabens in different organisms.

\begin{tabular}{cccc}
\hline Parabens(s) & Organism & Results & Reference \\
\hline MP & Rabbit & For dogs, the lethal dose $\left(\mathrm{LD}_{100}\right)$ was about $4000 \mathrm{mg} / \mathrm{kg}$ of PP and for \\
$\mathrm{PP}$ & rabbits this was $6000 \mathrm{mg} / \mathrm{kg}$ of PP. Regarding $\mathrm{MP}$, the values were & [21,22,102] \\
& & Tong $\mathrm{mg} / \mathrm{kg}$ for both. & \\
\hline
\end{tabular}


Table 3. Cont.

\begin{tabular}{|c|c|c|c|}
\hline Parabens(s) & Organism & Results & Reference \\
\hline $\begin{array}{l}\mathrm{MP} \\
\mathrm{PP}\end{array}$ & Mouse & $\begin{array}{l}\text { Orally, the } \mathrm{LD}_{50} \text { was higher than } 8000 \text { and } 2000 \mathrm{mg} / \mathrm{kg} \text { for MP and its sodium } \\
\text { salt, and above this dose some paralysis can appear in mice. } \\
\text { For propylparaben and its sodium salt, the } \mathrm{LD}_{50} \text { was higher than } 8000 \mathrm{mg} / \mathrm{kg} \\
\text { and higher than } 3700 \mathrm{mg} / \mathrm{kg} \text { by oral administration, respectively. } \\
\text { Recovery occurred quickly from nonfatal doses of MP or PP and their salts. } \\
\text { The } \mathrm{LD}_{50} \text { values for MP and its sodium salt by intraperitoneal administration } \\
\text { were } 960 \text { and } 760 \mathrm{mg} / \mathrm{kg} \text {, respectively, and about } 170 \mathrm{mg} / \mathrm{kg} \text { for its salt by } \\
\text { intravenous injection. } \\
\text { The intraperitoneal } \mathrm{LD}_{50} \text { values were } 640 \text { and } 490 \mathrm{mg} / \mathrm{kg} \text { for PP and its salt, } \\
\text { respectively. A reversible degree of paralysis was observed for an } \\
\text { intraperitoneal injection of } 400 \mathrm{mg} / \mathrm{kg} \text { of PP. } \\
\text { The sodium salt of PP showed an LD } 50 \text { of } 180 \mathrm{mg} / \mathrm{kg} \text {, and the intravenous } \\
\text { injection of this salt led to paralysis for } 50 \mathrm{mg} / \mathrm{kg} \text {. } \\
\text { Fatal dose of MP and its sodium salt produces ataxia, deep depression of } \\
\text { nervous system and quick death. } \\
\text { The authors suggest that the decrease in toxicity as the alkyl chain increases } \\
\text { must be related to a longer hydrolyzation time. }\end{array}$ & {$[19,21,22,103]$} \\
\hline PP & Mouse & $\begin{array}{l}\text { The } \mathrm{LD}_{50} \text { was } 6322 \mathrm{mg} / \mathrm{kg} \text {. } \\
\begin{array}{l}\text { Fatal dose of paraben or its salt caused a quick loss of muscular control (ataxia), } \\
\text { deep depression of the central nervous system and quick death. }\end{array}\end{array}$ & {$[22,86]$} \\
\hline $\begin{array}{l}\mathrm{MP} \\
\mathrm{PP}\end{array}$ & Rat & The $\mathrm{LD}_{50}$ subcutaneous dose was $1200 \mathrm{mg} / \mathrm{kg}$ for MP and $1650 \mathrm{mg} / \mathrm{kg}$ for PP. & {$[21,22,104]$} \\
\hline $\begin{array}{l}\mathrm{MP} \\
\mathrm{PP}\end{array}$ & Rat & $\begin{array}{l}\text { The oral dose was } 8000 \mathrm{mg} / \mathrm{kg} \text { and the intraperitoneal dose was } 640 \mathrm{mg} / \mathrm{kg} \text { for } \\
\text { PP and for MP doses } 8000 \text { and } 960 \mathrm{mg} / \mathrm{kg} \text {, respectively. }\end{array}$ & {$[21,22,38]$} \\
\hline MP & Mouse & $\begin{array}{l}\text { MP in } 0.85 \% \text { saline was administrated orally using doses of } 100-5000 \mathrm{mg} / \mathrm{kg} \text {. } \\
\text { The acute toxicity of } \mathrm{LD}_{50} \text { was estimated to be } 2100 \mathrm{mg} / \mathrm{kg} \text {, since all the mice } \\
\text { ingesting a dose of } 5000 \mathrm{mg} / \mathrm{kg} \text { died after } 24 \mathrm{~h} \text {. Some reddened gastric mucosa } \\
\text { and congested lungs were observed. } \\
\text { For MP in a saline suspension of } 21.8 \% \text { at a dose of } 5000 \mathrm{mg} / \mathrm{kg} \text {, no toxic effect } \\
\text { was observed, and this } \mathrm{LD}_{50} \text { was estimated to be higher than } 5000 \mathrm{mg} / \mathrm{kg} \text {. } \\
\text { For saline suspension of } 37-79 \% \text {, doses of } 2600-5600 \mathrm{mg} / \mathrm{kg} \text { were administrated, } \\
\text { and no toxic effects occurred, concluding in an } \mathrm{LD}_{50} \text { superior to } 5600 \mathrm{mg} / \mathrm{kg} \text {. }\end{array}$ & {$[21,105]$} \\
\hline MP & Fish & $\begin{array}{l}\text { The } \mathrm{LC}_{50} \text { Zebrafish embryo-larvae for MP was } 428 \mu \mathrm{M}(0.065 \mathrm{mg} / \mathrm{L}) \text { in } 96 \mathrm{~h} \\
\text { postfertilization. }\end{array}$ & [98] \\
\hline
\end{tabular}

\section{Legislation}

\subsection{Parabens, Pollutants and Discharge Policies}

Switzerland is the only country worldwide with specific legislation for the release of CECs $[8,12]$. The European Union (EU) does not have special legislation for CEC discharges, despite the existence of directives regarding quality and water policy.

The directive $N^{\circ} 76 / 464$ [106] of the European Communities Council (ECC) establishes rules for the discharges of dangerous substances and the pollution of water sources, encompassing some groups of compounds. The directive (CEE) $\mathrm{N}^{\circ} 80 / 68$ [107] regulates the policies for dangerous substances that are related to groundwater. For both directives, parabens are not directly involved, but can be considered to be in the "carcinogenic substances" group.

The directive (EU) $N^{\circ} 75 / 2010$ [108] indicates some guidelines for industrial emissions and presents the compounds that are considered as air and water pollutants. Parabens are not directly considered as pollutants but are indirectly considered, since carcinogenic substances and substances that alter chemical oxygen demand (COD) and biochemical oxygen demand (BOD) are considered as pollutants. This directive also indicates that the substances present in directive $\mathrm{N}^{\circ} 60 / 2000$ [109] of the European Community (EC) (which was already updated by directive (EC) $\mathrm{N}^{\circ}$ 105/2008 [110] and directive (EU) $\mathrm{N}^{\circ}$ 39/2013 [111]) 
are considered as water pollutants, but once again, the paraben family are not part of it. The directive (EU) $N^{\circ} 39 / 2013$ [111] regulates and classifies some priority substances in water policy.

The directive (ECC) $\mathrm{N}^{\circ} 271 / 91$ [112] indicates discharge parameters for wastewater treatment stations of urban wastewater. It also contemplates the criteria for identification of "sensitive zones", where the discharge rules are more restricted, and some sampling indications.

The EU has had a watchlist of compounds to monitor since 2015 [12,113]. The first step for the creation of thi list was implemented by EU directive No 39/2013 [101] contemplating some rules and directives for the first EU watchlist. Then, the first watchlist was made official by UE decision No 495/2015 [114], contemplating 17 substances. In 2018, this list was updated by decision No 840/2018 [115] currently comprising 15 compounds, but parabens are not a part of it.

Despite the considerations of European Union, the US Environmental Protection Agency (EPA) considers parabens as an emerging environmental pollutant [4].

\subsection{Paraben Legislation for Industrial Use in European Union}

The European Union is updating the regulations for the use of parabens is some industries.

Regarding the food industry, the use of additives is contemplated in regulation (EC) $\mathrm{N}^{\circ} 1333 / 2008$ [116] but was already updated by regulation (EU) $n^{\circ} 1129 / 2011$ [117] and regulation (EU) $n^{\circ} 1130 / 2011$ [118]. The updates were related to the authorized food additives and the conditions of their use, depending on the type of food, and the creation of a list of substances allowed to be used in food additives, food enzymes, food flavors and nutrients, and their guidelines of use. Regulation (EU) $n^{\circ} 1130 / 2011$ [118] authorizes the use of MP and EP but with restrictions, such as a maximum amount in preparation of enzymes that cannot exceed $2000 \mathrm{mg} / \mathrm{kg}$, restricted to $2 \mathrm{mg} / \mathrm{kg}$ for use in food and limited to $1 \mathrm{mg} / \mathrm{L}$ for use in drinks. Regulation (EU) $\mathrm{N}^{\circ} 231 / 2012$ [119] establishes the necessary characteristics for the use of food additives.

Regarding the cosmetic industry, regulation (EC) $N^{\circ} 1223 / 2009$ [120] establishes the standards for these products on European markets, which were already amended by regulation (EU) $\mathrm{N}^{\circ} 358 / 2014$ [121] and regulation (EU) $\mathrm{N}^{\circ}$ 1004/2014 [122]. These changes banned the use of some substances in cosmetic products, such as iso-propylparaben and its salts, as well as iso-butylparaben and its salts-phenylparaben, benzylparaben and pentylparaben. On the other hand, methylparaben and ethylparaben, their salts and derivatives, and propylparaben, butylparaben and their derivatives are authorized substances.

These updates also brought new restrictions. The uses of MP and EP are restricted to maximum concentrations of $0.4 \%$ and $0.8 \%$ for a single ester or a mixture of ester, respectively. Additionally, $\mathrm{PP}$ and $\mathrm{BuP}$ can only be used up to a maximum concentration of $0.14 \%$ for the sum of individual concentrations and $0.8 \%$ for mixtures of MP, EP, PP and $\mathrm{BuP}$, where the sum of PP and $\mathrm{BuP}$ and their salts does not exceed $0.14 \%$. The other huge restriction is the ban of use of PP and BuP and their salts in products for children under 3 years old, such as unrinsed products designed for application to covered areas by diapers.

In the pharmaceutical industry, the maximum concentration of parabens in pharmaceuticals is usually around 1\% [22]. For oral formulations, MP and PP are used within a concentration ranges of $0.015-0.2 \%$ and $0.01-0.02 \%$, respectively. Regarding the labeling and package leaflet of human's pharmaceutical products procedures, if a product contains in its composition parabens, that information must be provided, and, also, the use of antimicrobial preservatives in a medical product needs justification. The guidelines also say that these types of compounds must be avoided, especially in products aimed at children, and, when they are used, their quantities should be as low as possible. 
In pharmaceutical formulations, EMAs do not restrict the use of MP since they have not been associated to adverse effects, but, on the other hand, the use of PP is restricted to a No Observable Effect Level (NOEL) of $100 \mathrm{mg} / \mathrm{kg} /$ day, due to its associated estrogenic effects.

In general, the regulations already consider restrictions and prohibitions for the use of some parabens. In the food industry, the most common parabens are MP, EP and PP, but PP is not allowed in Europe; for the cosmetic industry the most used ones are MP and PP [22], but $\mathrm{EP}$ and $\mathrm{BuP}$ are also allowed; regarding the pharmaceutical industry, the most common are MP and PP, but the use of PP is restricted by EMA to a NOEL of $100 \mathrm{mg} / \mathrm{kg} / \mathrm{day}$.

\subsection{Other Paraben Legislation and Considerations Regarding Countries Outside the EU}

In the United States, the use of parabens is allowed without restrictions in cosmetics, but some cosmetics manufacturers are starting to use other alternative preservatives or decrease the use of parabens due do the increase in concerns $[20,123]$. However, the Cosmetic Ingredient Review Organization already recommended adopting the same restrictions as the EU for the use of parabens in the USA and Canada [20]. These countries do not have special legislation for the use of parabens in cosmetics, but the governmental units of the USA and Canada recommended the same rules regarding paraben concentrations in cosmetics as the ones established by the European Union [34].

Some entities such as ECORCERT (France), BDIH (Germany), NaTrue (Belgium), Soil Association (United Kingdom), ICEA (Italy) and BIOCOSC (Switzerland) are taking the same measures as the EU and are not allowing products with parabens in their compositions and other entities, such as CosmeBio, have forbade the use of parabens in cosmetics since 2002 [20]. Denmark has implemented different restrictions for propylparaben, butylparaben, iso-propylparaben and iso-butylparaben since 2011, but only for products for children under 3 years old [34].

The US Food and Drug Administration (FDA) considered MP and PP as inactive ingredients when used in dentifrices, contraceptives, analgesics, injection drugs, inhalation and intranasal solutions, ophthalmic, oral, topical, rectal, and vaginal drugs [22]. For food additives, FDA authorized the use of parabens and consider the use of methylparaben and propylparaben as safe up to a limit of $0.1 \%$ [21,22]. Additionally, the joint FAO/WHO Expert Committee established a daily intake sum of MP, EP and PP of $10 \mathrm{mg} / \mathrm{kg}$ [22].

It is not easy to find information about the use of parabens in pharmaceuticals, cosmetics and food from the USA and China, but it seems that the FDA did not update their regulations regarding parabens, since there are no restrictions for their use in cosmetics, as already mentioned, and there is no contradictory information to the values given by Soni et al. [21,22] for food application. Regarding China, no works or other sources with the desired information were found, but a website states that the last update of cosmetic legislation occurred in 2015, allowing use of MP, EP, PP, BuP, iso-PP and iso-BuP and their sodium and potassium salts in cosmetics in China [124]. Another website, from an update made in 2018, refers to a list of ingredients as a proposal for amendment of the existing regulations, referring only to $\mathrm{MP}, \mathrm{EP}, \mathrm{PP}$ and $\mathrm{BuP}$ and their salts as authorized substances, using the same restrictions as the EU [125]. If this is confirmed, then China has updated their regulations regarding the use of parabens in the cosmetic industry.

In Japan, some parabens (ethyl-, propyl-, iso-propyl-, butyl- and n-butyl- parabens) are allowed for use as food additives, and their limits are regulated as the total quantity of p-hydroxybenzoic acid [22], and in cosmetic products, the maximum paraben concentration allowed is $1 \%$ [34].

In accordance with the previous information, it is possible to see a lack of important action. Although the legislation for industrial use of parabens is being updated and being more restricted, the reality still provides the presence of these compounds in nature, and some studies still refer to parabens as source of different problems for human health. More restrictions regarding paraben use should be enforced and more studies about the risks of parabens must be carried out in order to have more scientific information that allows a decision to be made based on solid and irrefutable arguments. 
Regarding the existence of parabens in water resources, the legislation and recommendations must be urgently updated. Parabens are ubiquitous in nature and this must be reverted, since ecosystems and their fauna and flora could suffer different impacts caused by the presence of these and other compounds in waters. Around the world, only one country shows special regulations against CECs; this needs to be changed, since water pollution is a worldwide reality.

This problem can only be reverted by the adoption of new measures, which must go through updated legislation, monitorization of different CECs and the implementation of new or current methods that guarantee the correct elimination of these products by the WWTPs.

\subsection{Detection of Parabens in Products and Concentration of Use in Industrial Products}

Parabens are widely used in the PPCP and foodstuff industries as preservatives. In food, parabens are already used in concentration ranges between 450 and 2000 ppm [22].

For methylparaben, the levels approved by the Flavor and Extract Manufacturers Association (FEMA) for foodstuff are between 0.00 ppm for milk products, cheese, frozen dairy products, meat products, soft candy, gelatin pudding and nonalcoholic beverages up to a maximum of $1.00 \mathrm{ppm}$ for processed vegetables [21]. Regarding propylparaben, the approved level by FEMA for food products are comprised between $0.06 \mathrm{ppm}$ for soft candy and frozen dairy products and $1.00 \mathrm{ppm}$ for processed vegetables, and up to a maximum level of $1.00 \mathrm{ppm}$ for fats and oil and processed vegetables [22].

In pharmaceutical industries, MP is used at $0.065-0.25 \%$ in injections, $0.015-0.05 \%$ in ophthalmic preparation, between $0.015 \%$ and $0.2 \%$ in oral solutions and suspensions, at $0.02-0.3 \%$ in topical preparations and at $0.1-0.18 \%$ in vaginal preparations [21]. For cosmetics, single or combined parabens are used to extend the lifetime of the product, and it is estimated that the preferential parabens for cosmetics are methyl- > ethyl- > propyl- > butyl- > benzylparaben [19,126].

A study carried out by the United States Centers for Disease Control and Prevention (CDC) showed the presence of MP and PP in more than $90 \%$ of urine samples from the US general population in concentrations of $\mathrm{ng} / \mathrm{mL}$ [23]. A study of exposure to parabens in foodstuff from Albany, New York, concluded that in more than $90 \%$ of food samples it was possible to detect parabens and measure their concentrations, which ranged from the minimum quantification level up to $409 \mathrm{ng} / \mathrm{g}$ fresh weight for the sum of MP, EP, PP, BuP and BeP. In that study the mean level was $9.67 \mathrm{ng} / \mathrm{g}$, the median was $0.92 \mathrm{ng} / \mathrm{g}$, and MP, $\mathrm{EP}$ and PP was the most found parabens (about $90 \%$ of total concentrations). The estimated daily intake (EDI) calculated for the total parabens regarding food ingestion was 940, 879, 470, 273 and $307 \mathrm{ng} / \mathrm{kg}$ of body weight/day for infants, toddlers, children, teenagers, and adults, respectively [23].

Liao et al. [24] analyzed the occurrence of parabens in foodstuff from China, considering more than 282 samples of different foods. MP, EP, PP, BuP, BeP and HeP were detected at general mean levels (considering all the samples) of 22.4, 11, 5.22, 0.607, 0.086 and $0.005 \mathrm{ng} / \mathrm{g}$. The authors also estimated the mean levels for EDI achieving a total paraben ingestion of 1010 and $1060 \mathrm{ng} / \mathrm{kg}$ of body weight/day for male and females, respectively.

Guo and Kannan [25] detected parabens in PPCPs from the United States, with total mean values of 482, 25.4, 143, 76.7, 0.06 and $0.02 \mu \mathrm{g} / \mathrm{g}$ wet weight for MP, EP, PP, BuP, BeP and $\mathrm{HeP}$ for rinse-off products (as shampoo, hair conditioner, shaving gel, etc.), 466, 84.2, $182,50.6$ and $0.03 \mu \mathrm{g} / \mathrm{g}$ wet weight for MP, EP, PP, BuP and BeP in leave-on products (skin lotion, hair care products, perfume, skin toner, deodorant, sunscreen, creams, etc.) and totals of $640,151,338,12.3,0.86 \mu \mathrm{g} / \mathrm{g}$ wet weight for MP, EP, PP, BuP and BeP in baby care products (shampoo, lotion and oil, diaper cream, sunscreen and powder). The estimated daily intakes by dermal absorption (mean values) for total parabens are 0.84 and $77.1 \mu \mathrm{g} / \mathrm{kg}$ body weight/day for rinse-off and leave-on PPCPs of adult females (21-60 years old), and 322 and $200 \mu \mathrm{g} / \mathrm{kg}$ body weight/day for infants (0-1 years old) and toddlers (2-3 years old), respectively. 
Guo et al. [127] studied the parabens in the constitution of PPCPs from China, and concluded the existence of parabens at mean values of 1200, 39.1, 746 and $30.9 \mu \mathrm{g} / \mathrm{g}$ of MP, EP, PP and BuP for face creams, 1120, 31.2, $596 \mu \mathrm{g} / \mathrm{g}$ of MP, EP and PP for body and hand lotions, 297, 1, 210 and $63 \mu \mathrm{g} / \mathrm{g}$ and 39, 5.1, 1 and $0.2 \mu \mathrm{g} / \mathrm{g}$ regarding face cleanser and shampoo samples, respectively, and $0.5,0.1$ and $0.1 \mu \mathrm{g} / \mathrm{g}$ of MP, EP and PP for bodywash products. The total mean values for daily exposure dose regarding all the parabens detected is $3620,15000,4.3,<0.1$ and $<0.1 \mu \mathrm{g} /$ day for face cream, hand or body lotion, face cleanser, hair shampoo and body wash respectively, making a total exposure dose (mean values) of $18,700 \mu \mathrm{g}$ /day regarding just the mentioned PPCPs.

A study carried out by Gao and Kannan [128] detected parabens in feminine hygiene products from Albany, New York. In pads, it was possible to find mean values of 45.5, $47.1,10.8$ and $0.97 \mathrm{ng} / \mathrm{g}$ of MP, EP, PP and BuP, while for panty liners it was possible to detect 152, 77.2, 17.8, 2.15 and $0.60 \mathrm{ng} / \mathrm{g}$ for MP, EP, PP, BuP and BeP. It was also found that for tampons these levels were 18.2, 27.6, 2.01, $0.06 \mathrm{ng} / \mathrm{g}$ for MP, EP, PP and BuP, respectively, and 418, 12564, 20.4, 0.91 and $0.38 \mathrm{ng} / \mathrm{g}$ of MP, EP, PP, BuP and BeP for wipes. For bactericidal creams and solutions, the mean values were $67,100,70,200,27,700,5.89$ and $8.62 \mathrm{ng} / \mathrm{g}$ for MP, EP, PP, BuP and BeP, and for deodorant sprays the values were 1590, $2100,188,0.26$ and $324 \mathrm{ng} / \mathrm{g}$ for the same order of parabens. In powders, the mean values were 997, 12.5, 352 and 6.76 for MP, EP, PP and BeP, respectively.

C. Li et al. [129] analyzed 50 human fingernails for parabens in China. Additionally, the authors analyzed 32 samples of face cream that were used by the participants, detecting geometric means of around 1550, 8.28, 1510, 6.29 and $0.16 \mathrm{ng} / \mathrm{g}$ and median values of 8450 , $5.57,832,10.4$ and $4.34 \mathrm{ng} / \mathrm{g}$ for MP, EP, PP, BuP, and BeP, respectively.

Since the studies of Gao and Kannan [128], Liao et al. [23] and Guo and Kannan [25] are from the USA, the use of parabens is not restricted [20], so it is expected that different parabens could be detected, but considering European Union legislation, the products reported in these studied could not be produced or marketed in EU space, since they present $\mathrm{MP}, \mathrm{EP}, \mathrm{PP}, \mathrm{BuP}$, and $\mathrm{BeP}$ in their compositions, and the European cosmetics and foods regulations do not allow the use of $\mathrm{BeP}$ in cosmetics and the use of $\mathrm{PP}, \mathrm{BuP}$ and $\mathrm{BeP}$ in foods. For the studies of Liao et al. [24], C. Li et al. [129] and Guo et al. [127], which are from China, the same can be concluded, since the analyzed products showed the presence of MP, EP, PP, BuP, BeP, and HeP.

\section{Paraben Detection}

In this section are reported results from the literature regarding the detection and quantification of parabens in different media.

\subsection{Detection in Water Soruces}

Parabens have been detected in various types of water sources such as rivers [130-132], tap water [133], pool water [134], effluents [76,135] and drinking water [133,136].

Some studies have good treatment performances, reaching efficiencies for conventional treatments of up to $90 \%[4,15]$. However, other studies find an inefficient capacity of degradation of parabens by conventional wastewater depuration techniques [8], so the detection of these compounds must be a matter of discussion. Even if WWTP conventional technologies are efficient, in reality parabens continue to be detected in water resources, showing their ubiquity, so, it is possible to conclude that even the smallest discharge of parabens by WWTP at a large scale when all WWTP discharges are added can impact on the environment, which may be important.

The continuous detection of these compounds in water sources must have an explanation that can be related to a greater use of parabens in industries, population growth, which causes a higher consumption of products that contain parabens, the inefficiency of treatments or even the design of treatment plants that can be outdated for the types of effluents that currently exist. These reasons are just a few of many that can be the main 
cause for the continuous detection of parabens in various types of water sources, with the effluent discharges being the main cause for the appearance of parabens.

\subsubsection{Paraben Detection in WWTPs}

Some authors emphasize the discharge of domestic and industrial wastewater effluents as the main route for the appearance of parabens in nature. Additionally, other authors report discharge of parabens as a result of an inefficient treatment of wastewater treatment plants.

Few authors have studied the detection of several CECs, such as parabens, in WWTP water samples from different stations located around the globe. Table 4 elaborates on some of these studies, where it is possible to see, in general, that the stations allow the emission of parabens to water resources, but also, it is possible to see that some treatment plants can remove parabens.

Table 4. Paraben detection in wastewater treatment plants (WWTPs).

\begin{tabular}{|c|c|c|c|c|}
\hline Local & Detection Source & $\begin{array}{c}\text { Influent Range of } \\
\text { Concentration/[ng/L] }\end{array}$ & $\begin{array}{c}\text { Effluent Range of } \\
\text { Concentration/[ng/L] }\end{array}$ & Reference \\
\hline $\begin{array}{l}\text { Santiago de Compostela, } \\
\text { Galicia, Spain }\end{array}$ & LC/ESI-MS/MS & $\begin{array}{c}\text { MP: } 1926-5138 \\
\text { EP: } 452-549 \\
\text { i-PP: }<0.38-4.6 \\
\text { n-PP: } 1147-1302 \\
\text { i-BuP: } 83.6-89.1 \\
\text { n-BuP: } 150-181 \\
\text { BeP: }<0.2\end{array}$ & $\begin{array}{c}\text { MP: }<1.11-1.5 \\
\text { EP: }<0.34 \\
\text { i-PP: }<0.38 \\
\text { n-PP: }<0.28 \\
\text { i-BuP: }<0.12 \\
\text { n-BuP: }<0.21-3.6 \\
\text { BeP: }<0.2\end{array}$ & {$[135]^{\mathrm{a}}$} \\
\hline $\begin{array}{l}\text { Santiago de Compostela, } \\
\text { Galicia, Spain }\end{array}$ & $\begin{array}{l}\text { NACE-DAD } \\
\text { NACE-DAD-LVSS }\end{array}$ & $\begin{array}{l}\text { MP: 524-3259 } \\
\text { EP: 187-202 } \\
\text { PP: 756-904 } \\
\text { BeP: 0-655 }\end{array}$ & $\begin{array}{c}\text { MP: }<30-112 \\
\text { EP: } 0.0-30 \\
\text { PP: 0.0-44 } \\
\text { BuP: }<25-83 \\
\text { BeP: } 0.0-90\end{array}$ & {$[137]^{b}$} \\
\hline Valencia, Spain & $\mathrm{LC} / \mathrm{MS}$ & $\begin{array}{l}\text { MP: } 334 \\
\text { EP:72 } \\
\text { PP: } 163 \\
\text { BuP: } 15\end{array}$ & MP: 11 & {$[133]^{c}$} \\
\hline Leipzig, Germany & GC/MS & $\begin{array}{c}\text { MP: }<6.17 \\
\text { iPP: }<2.14 \\
\text { nPP: } 502 \\
\text { BuP: }<3.55 \\
\text { BeP: }<9.35\end{array}$ & $\begin{array}{c}\text { MP: }<6.17 \\
\text { iPP: }<2.14 \\
\text { nPP: }<13.74 \\
\text { BuP: }<3.55 \\
\text { BeP: }<9.35\end{array}$ & {$[138]^{\mathrm{c}}$} \\
\hline Spain & $\mathrm{LC} / \mathrm{MS}$ & $\begin{array}{l}\text { MP: } 9.0-157 \\
\text { EP: } 14-814 \\
\text { PP: } 16-913\end{array}$ & $\begin{array}{l}\text { MP: } 0-40 \\
\text { EP: } 0-6.8 \\
\text { PP: } 0-24 \\
\text { BeP: } 0-1.7\end{array}$ & [76] \\
\hline South Wales, United Kingdom & UPLC/MS & $\begin{array}{c}\text { MP: } 661-15,646 \\
\text { EP: } 192-1918 \\
\text { PP: }<2-1703 \\
\text { BuP: }<2-114\end{array}$ & $\begin{array}{c}\text { MP: }<3-155 \\
\text { EP: }<0.6-69 \\
\text { PP: }<1-95 \\
\text { BuP: }<1\end{array}$ & [139] \\
\hline South Wales, United Kingdom & UPLC/MS & $\begin{array}{c}\text { MP: } 4550-30,688 \\
\text { EP: } 715-3312 \\
\text { PP: } 820-8286 \\
\text { BuP: } 274-1595\end{array}$ & $\begin{array}{c}\text { MP: }<3-36 \\
\text { EP: }<0.6-43 \\
\text { PP: }<1-84 \\
\text { BuP: }<1-2\end{array}$ & [139] \\
\hline
\end{tabular}


Table 4. Cont.

\begin{tabular}{|c|c|c|c|c|}
\hline Local & Detection Source & $\begin{array}{c}\text { Influent Range of } \\
\text { Concentration/[ng/L] }\end{array}$ & $\begin{array}{c}\text { Effluent Range of } \\
\text { Concentration/[ng/L] }\end{array}$ & Reference \\
\hline Harbin, China & HPLC/MS-MS & $\begin{array}{l}\text { MP: } 968-1310 \\
\text { EP: } 133-362 \\
\text { PP: } 364-496 \\
\text { BuP: } 29.3-7.00 \\
\text { BeP: } 6.09-2.32\end{array}$ & $\begin{array}{c}\text { MP: } 57.6-18.2 \\
\text { EP: } 1.90-0.94 \\
\text { PP: } 8.11-0.37 \\
\text { BuP: } 0.01-0.16 \\
\text { BeP: 0-2.63 }\end{array}$ & {$[140]^{\mathrm{d}}$} \\
\hline Copenhagen, Denmark & $\mathrm{LC} / \mathrm{MS}$ & $\begin{array}{c}\text { MP: } 16,322-17,462 \\
\text { EP: } 9193-10,519 \\
\text { PP: } 12,105-18,631 \\
\text { BuP: } 4483-5641 \\
\text { BeP: } 12.4-13.5\end{array}$ & $\begin{array}{c}\text { MP: }<2.8-262 \\
\text { EP: }<1.9-290 \\
\text { PP: 49.9-231 } \\
\text { BuP: 4.6-550 } \\
\text { BeP: }<1.2\end{array}$ & {$[141]^{\mathrm{d}}$} \\
\hline Albany, New York, USA & HPLC/MS & $\begin{array}{l}\text { MP: } 36.8-97.9 \\
\text { EP: } 2.74-4.00 \\
\text { PP: } 12.9-20.9 \\
\text { BuP: } 5.8-7.25 \\
\text { BeP: } 0.07\end{array}$ & $\begin{array}{c}\text { MP: } 0.14 \\
\text { EP: } 0.14-0.3 \\
\text { PP: } 0.51-1.16 \\
\text { BuP: } 0.14-0.61 \\
\text { BeP: } 0.07\end{array}$ & {$[140,142]^{\mathrm{e}}$} \\
\hline India & HPLC/ESI-MS & $\begin{array}{c}\text { MP: } 38.2-267 \\
\text { EP: } 4.1-68.1 \\
\text { PP: } 38.2-583 \\
\text { BuP: } 4.1-10.5 \\
\text { BeP: } 0-8.2\end{array}$ & $\begin{array}{c}\text { MP: } 4.4-41 \\
\text { EP: } 1.9-9.8 \\
\text { PP: } 2.8-19.3 \\
\text { BuP: 0-2.9 } \\
\text { BeP: 0-2.9 }\end{array}$ & {$[140,143]^{\mathrm{d}}$} \\
\hline
\end{tabular}

${ }^{\mathrm{a}}$ —range based on samples of different months; ${ }^{\mathrm{b}}$-range based on different samples; ${ }^{\mathrm{c}}$ —only shows mean values; ${ }^{\mathrm{d}}$-mean values and based on different WWTPs; ${ }^{\text {e }}$ - median values and based in different WWTPs.

Blanco et al. [137] detected parabens in WWTP influent and effluent samples near Santiago de Compostela, Spain. This work suggests some paraben removal in the WWTP since a small fraction of parabens was emitted to the water ecosystems.

Casas-Ferreira et al. [138] detected these compounds from influent and effluent samples from a WWTP located in Leipzig, Germany, which revealed a poor capacity of conventional treatment.

Kasprzyk-Hordern et al. [139] studied the presence of parabens in influents and effluents of two WWTPs from South Wales, United Kingdom. The results show that Cilfynydd station (equipped with trickling beds) removed about $98.23 \%, 93.55 \%, 94.15 \%$ and almost 100\% of MP, PP, EP and BuP, respectively. For the Coslech WWTP (equipped with activated sludge), the removal rates were about $99.92 \%, 99.80 \%, 99.99 \%, 99.16 \%$ and $100 \%$ for the same parabens.

Figure 1 and Table 4 present the range of paraben concentrations of the influent and effluent samples from different WWTPs.

In all the studies mentioned, it is possible to conclude that paraben abatement occurs in the analyzed WWTPs. However, all the effluent samples had at least one paraben at ng/L scale in their compositions, which means that in reality these compounds cannot be fully removed in WWTPs. It is important to mention that the WWTP effluents are discharged in water resources, generally rivers, and that discharge must obey specific legislation and emission values, such as BOD and COD, among other parameters that are also regulated.

Although legislation does not show specific emission values for parabens, it has specific BOD and COD values, and since paraben can interfere with these values, it is important to guarantee that these residual parabens, among others organic compounds, are not sufficient to exceed the legal limits. Still, it is likely that legislation will go towards the path of stablishing limits for specific contaminants of emerging concern due to their potential impact even at low concentrations. 


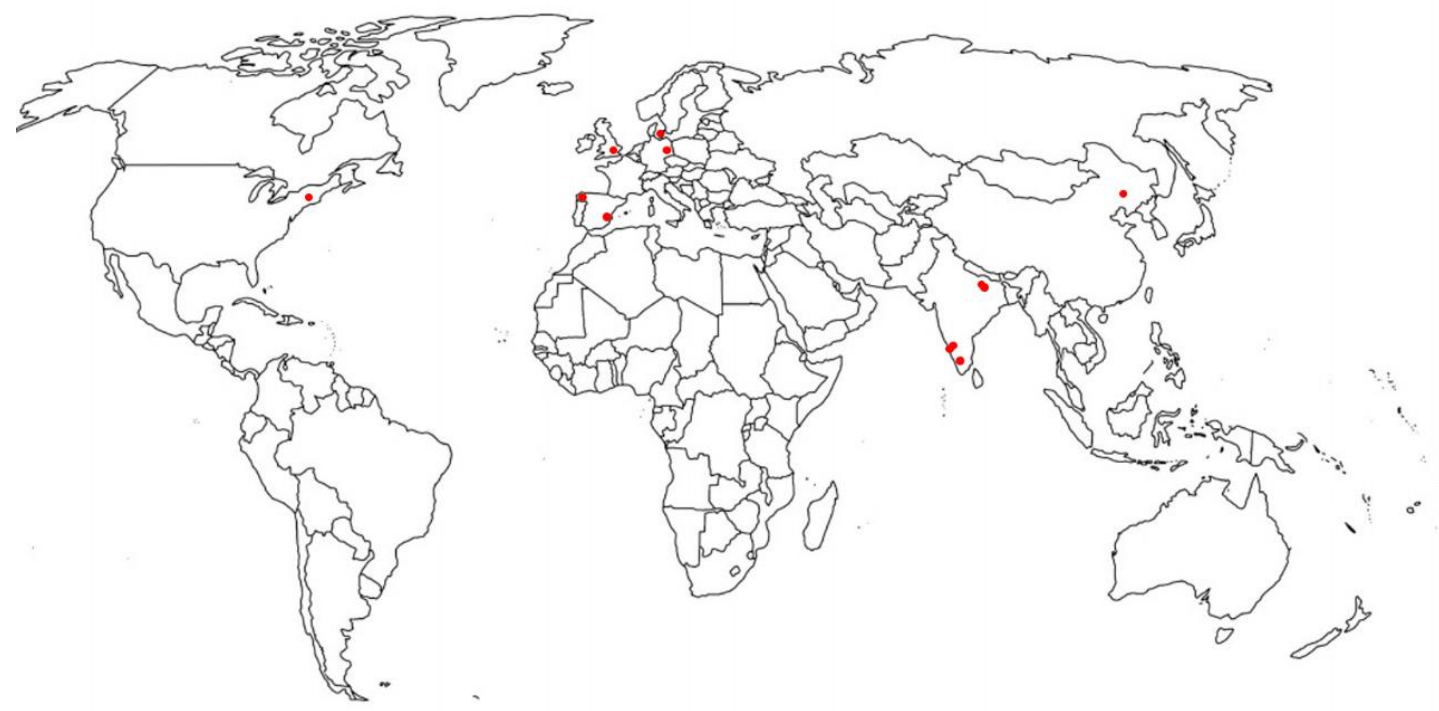

Figure 1. Geographic location of paraben detection in WWTPs.

\subsubsection{Paraben Detection in Water Resources}

Carmona et al. [133] detected 21 PPCPs in drinking water from different shops, tap water from different addresses and surface water of Túria river, Valencia, Spain. Parabens such as MP, EP, PP and BuP were found in river and bottled water samples, and MP, PP and BuP in tap water samples.

Jonkers et al. [132] investigated the occurrence of CECs in Ria de Aveiro, Aveiro, Portugal. Parabens (MP, EP, PP, BuP and BeP) were found in concentrations of ng/L in several rivers, in city channels and sea.

Kasprzyk-Hordern et al. [130,139] detected more than 55 PPCPs. EDs and illicit drugs in Taff and Ely rivers, South Wales, United Kingdom-MP, EP, PP and BuP were found.

Casas-Ferreira et al. [138] detected five parabens (MP, BuP, BeP, iso-PP and n-PP) and triclosan at concentrations of $17,<3.55,<9.35,<2.14,<13.74$, and $<4.65 \mathrm{ng} / \mathrm{L}$, respectively, in tap water samples from Leipzig, Germany.

González-Marino et al. [135] studied the existence of CECs in Santiago de Compostela, Spain and detected seven parabens, triclosan and triclocarban. Jonkers et al. [144] found MP, EP, PP, BuP and BeP in Glatt River, Switzerland.

Figure 2 shows the geographic locations and Table 5 reports the detection of parabens from different locations around the world at different concentrations.

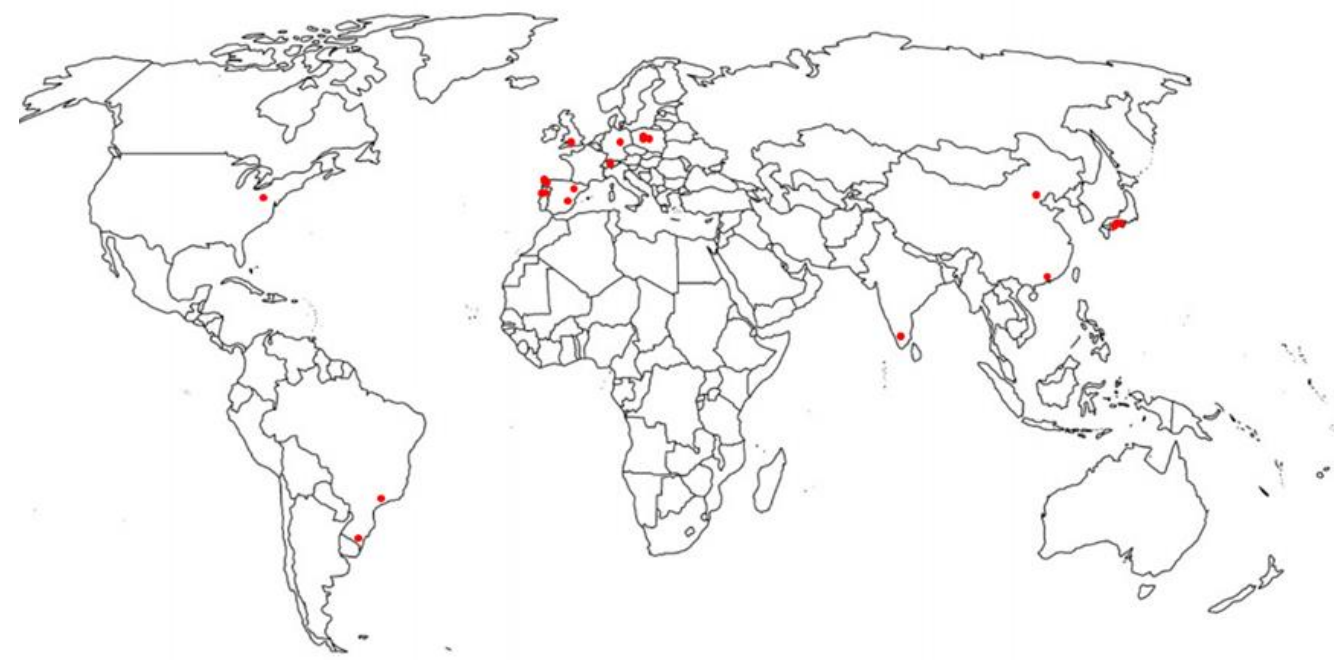

Figure 2. Geographic locations of parabens detected in water sources. 
Table 5. Paraben detected in several water sources.

\begin{tabular}{|c|c|c|c|c|}
\hline Local & Source & Detection Source & $\begin{array}{c}\text { Range of } \\
\text { Concentration/[ng/L] }\end{array}$ & Reference \\
\hline Beijing, China & Pool Water & HPLC/MS & $\begin{array}{l}\text { MP: 0.16-872 } \\
\text { EP: 0-110 } \\
\text { PP: 0-266 } \\
\text { BuP: 0-49.2 } \\
\text { BeP: 0-6.52 } \\
\text { HeP: } 0-0.06\end{array}$ & [134] \\
\hline $\begin{array}{l}\text { Taff River, South Wales, } \\
\text { United Kingdom }\end{array}$ & Surface Water-River & UPLC/MS & $\begin{array}{c}\text { MP: }<0.3-150 \\
\text { EP: }<0.5-12 \\
\text { PP: }<0.2-11 \\
\text { BuP: }<0.3\end{array}$ & [130] \\
\hline $\begin{array}{l}\text { Ely River, South Wales, } \\
\text { United Kingdom }\end{array}$ & Surface Water-River & UPLC/MS & $\begin{array}{c}\text { MP: }<0.3-400 \\
\text { EP: }<0.5-15 \\
\text { PP: }<0.2-24 \\
\text { BuP: }<0.3-52\end{array}$ & [130] \\
\hline $\begin{array}{l}\text { Taff River, South Wales, } \\
\text { United Kingdom }\end{array}$ & Surface Water-River & UPLC/MS & $\begin{array}{c}\text { MP: }<0.3-150 \\
\text { EP: }<0.5-12 \\
\text { PP: }<0.2-11 \\
\text { BuP: }<0.3\end{array}$ & [139] \\
\hline $\begin{array}{l}\text { Ely River, South Wales, } \\
\text { United Kingdom }\end{array}$ & Surface Water-River & UPLC/MS & $\begin{array}{c}\text { MP: }<0.3-305 \\
\text { EP: }<0.5-15 \\
\text { PP: }<0.2-22 \\
\text { BuP: }<0.3-16\end{array}$ & [139] \\
\hline Beijing, China & Surface Water-River & HPLC/MS & $\begin{array}{l}\text { MP: 0.81-920 } \\
\text { EP: 0-294 } \\
\text { PP: 0-565 } \\
\text { BuP: 0-41.5 } \\
\text { BeP: 0-3.93 } \\
\text { HeP: 0-2.94 }\end{array}$ & [1] \\
\hline $\begin{array}{l}\text { Santiago de Compostela, } \\
\text { Galicia, Spain }\end{array}$ & Surface Water-River & LC/ESI-MS/MS & $\begin{array}{c}\text { MP: } 1.8-17.3 \\
\text { EP: } 0.13-3.0 \\
\text { BeP: }<0.08 \\
\text { i-PP: }<0.15 \\
\text { n-PP: }<0.11-69 \\
\text { i-BuP: }<0.05-4.6 \\
\text { n-BuP: }<0.08-7.0\end{array}$ & {$[135]^{\mathrm{a}}$} \\
\hline Glatt River, Switzerland & Surface Water-River & $\mathrm{LC} / \mathrm{MS}$ & $\begin{array}{c}\text { MP: } 3.1-17 \\
\text { EP: }<0.3-1.6 \\
\text { PP: }<0.5-5.8 \\
\text { BuP: }<0.2-2.8 \\
\text { BeP: }<0.2-4.4\end{array}$ & [144] \\
\hline $\begin{array}{c}\text { Shizuoka City, Pacific Center } \\
\text { Region, Japan }\end{array}$ & Surface Water & GC/MS & $\begin{array}{l}\text { MP: } 0-5.4 \\
\text { EP: } 0-<4.3 \\
\text { PP: } 0-25 \\
\text { BuP: } 0-12\end{array}$ & [145] \\
\hline $\begin{array}{l}\text { Kaveri, Tamiraparani and } \\
\text { Vellar River, South India }\end{array}$ & Surface Water-River & GC/MS & $\begin{array}{c}\text { MP: } 0.0-22.8 \\
\text { EP: } 2.47-147 \\
\text { PP: } 0.0-57\end{array}$ & [146] \\
\hline Great Pittsburgh, USA & Surface Water & HPLC/MS & $\begin{array}{c}\text { MP: } 2.2-17.3 \\
\text { PP: 0-12.0 } \\
\text { BuP: 0-0.2 }\end{array}$ & {$[76]^{\mathrm{a}}$} \\
\hline
\end{tabular}


Table 5. Cont.

\begin{tabular}{|c|c|c|c|c|}
\hline Local & Source & Detection Source & $\begin{array}{c}\text { Range of } \\
\text { Concentration/[ng/L] }\end{array}$ & Reference \\
\hline $\begin{array}{c}\text { Águeda and Vouga River, } \\
\text { Portugal }\end{array}$ & Surface Water-River & HPLC/MS & $\begin{array}{c}\text { MP: }<1.6-45 \\
\text { EP: }<0.3-2.2 \\
\text { PP: }<0.5-6.2 \\
\text { BuP: }<0.2-0.8 \\
\text { BeP: }<0.2\end{array}$ & [132] \\
\hline $\begin{array}{l}\text { Caster and Antuã River, } \\
\text { Portugal }\end{array}$ & Surface Water-River & HPLC/MS & $\begin{array}{c}\text { MP: } 3.3-16 \\
\text { EP: }<0.3-6.4 \\
\text { PP: }<0.5-64 \\
\text { BuP: }<0.2-42 \\
\text { BeP: }<0.2-0.3\end{array}$ & [132] \\
\hline $\begin{array}{c}\text { Marine Coast of Aveiro, } \\
\text { Portugal }\end{array}$ & Surface Water-Sea Water & HPLC/MS & $\begin{array}{c}\text { MP: } 5.1-21 \\
\text { EP: }<0.3-1.6 \\
\text { PP: }<0.5-1.6 \\
\text { BuP: }<0.2-0.7 \\
\text { BeP: }<0.2\end{array}$ & [132] \\
\hline $\begin{array}{c}\text { Marine Coast of Aveiro, } \\
\text { Portugal }\end{array}$ & $\begin{array}{c}\text { Surface Water-Seaport } \\
\text { Water }\end{array}$ & HPLC/MS & $\begin{array}{c}\text { MP: } 6-24 \\
\text { EP: }<0.3-5.3 \\
\text { PP: }<0.5-5.3 \\
\text { BuP: }<0.2 \\
\text { BeP: }<0.2\end{array}$ & [132] \\
\hline City of Aveiro, Portugal & $\begin{array}{c}\text { Surface Water-Canal } \\
\text { Water }\end{array}$ & HPLC/MS & $\begin{array}{c}\text { MP: } 5.9-28 \\
\text { EP: }<0.3-3.2 \\
\text { PP: }<0.5-11 \\
\text { BuP: }<0.2-5.9 \\
\text { BeP: }<0.2\end{array}$ & [132] \\
\hline Lagoon in Aveiro, Portugal & Surface Water-Lagoon & HPLC/MS & $\begin{array}{c}\text { MP: } 2.1-51 \\
\text { EP: }<0.3-6.7 \\
\text { PP: }<0.5-7.9 \\
\text { BuP: }<0.2-0.2 \\
\text { BeP: }<0.2-0.3\end{array}$ & [132] \\
\hline Galicia, Spain & Tap Water & $\begin{array}{c}\text { NACE-DAD } \\
\text { NACE-DAD-LVSS }\end{array}$ & $\begin{array}{l}\text { MP: } 40 \\
\text { PP: }<25\end{array}$ & {$[137]^{\mathrm{a}}$} \\
\hline Galicia, Spain & Surface Water-River & $\begin{array}{l}\text { NACE-DAD } \\
\text { NACE-DAD-LVSS }\end{array}$ & $\begin{array}{c}\text { MP: }<30-37 \\
\text { EP: } 0-<30 \\
\text { PP: } 0-<25 \\
\text { BuP: } 0-<25 \\
\text { BeP: } 0-<31\end{array}$ & {$[137]^{\mathrm{a}}$} \\
\hline Túria River, Spain & Surface Water-River & $\mathrm{LC} / \mathrm{MS}$ & $\begin{array}{c}\text { MP: } 119 \\
\text { EP: } 16 \\
\text { PP: } 145 \\
\text { BuP: } 14\end{array}$ & {$[133]^{b}$} \\
\hline Spain & Tap Water & $\mathrm{LC} / \mathrm{MS}$ & $\begin{array}{c}\text { MP: } 12 \\
\text { PP: } 9 \\
\text { BuP: } 28\end{array}$ & {$[133]^{b}$} \\
\hline Spain & Bottled Water & LC/MS & $\begin{array}{c}\text { MP: } 40 \\
\text { EP: } 2 \\
\text { PP: } 23 \\
\text { BuP: } 36\end{array}$ & {$[133]^{b}$} \\
\hline
\end{tabular}


Table 5. Cont.

\begin{tabular}{|c|c|c|c|c|}
\hline Local & Source & Detection Source & $\begin{array}{c}\text { Range of } \\
\text { Concentration/[ng/L] }\end{array}$ & Reference \\
\hline Leipzig, Germany & Tap Water & GC/MS & 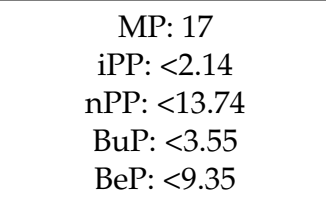 & {$[138]^{b}$} \\
\hline Rio Grande, Brazil & Bottled Water & $\mathrm{LC} / \mathrm{MS}$ & MP: 90-242 & [18] \\
\hline Tokushima, Japan & Surface Water-River & $\mathrm{LC} / \mathrm{MS}$ & $\begin{array}{c}\text { MP: 49-676 } \\
\text { EP: } 2.8-64 \\
\text { n-PP: 7.5-207 } \\
\text { i-PP: }<1.6-46 \\
\text { n-BuP: } 10-163 \\
\text { i-BuP: } 1.4-13 \\
\text { BeP: }<0.2-2.3\end{array}$ & {$[101]^{\mathrm{c}}$} \\
\hline Osaka, Japan & Surface Water-River & $\mathrm{LC} / \mathrm{MS}$ & $\begin{array}{c}\text { MP: } 25-199 \\
\text { EP: }<1.3-12 \\
\text { n-PP: }<0.8-20 \\
\text { i-PP: }<1.6 \\
\text { n-BuP: }<0.6-2.6 \\
\text { i-BuP: }<1.2 \\
\text { BeP: }<0.2\end{array}$ & {$[101]^{\mathrm{c}}$} \\
\hline Ebro River, Spain & Surface Water-River & $\mathrm{LC} / \mathrm{MS}$ & $\begin{array}{l}\text { MP: } 1.4-27 \\
\text { EP: } 0-13 \\
\text { PP: } 0.5-15 \\
\text { BeP: } 0-1.1\end{array}$ & [76] \\
\hline $\begin{array}{l}\text { Pearl River, Guangzhou, } \\
\text { China }\end{array}$ & Surface Water-River & GC/MS & $\begin{array}{l}\text { MP: }<0.5-1062 \\
\text { PP: } 5-3142\end{array}$ & [75] \\
\hline $\begin{array}{l}\text { Wielkopolska Voivodeship, } \\
\text { Poland }\end{array}$ & $\begin{array}{c}\text { Surface Water-River and } \\
\text { Lake }\end{array}$ & $\mathrm{LC} / \mathrm{MS}$ & $\begin{array}{c}\text { MP: } 1.7-1598 \\
\text { EP: } 0.8-27.5 \\
\text { PP: } 0.5-93.9 \\
\text { BuP: 0.6-22.6 } \\
\text { BeP: 0-31.0 }\end{array}$ & [147] \\
\hline Poland & $\begin{array}{c}\text { Surface Water-River and } \\
\text { Lake }\end{array}$ & $\mathrm{HPLC} / \mathrm{MS}$ & $\begin{array}{c}\text { MP: } 8.7-465.6 \\
\text { PP: 0-144.4 } \\
\text { BuP: 0-19.6 } \\
\text { BeP: 0-8.6 }\end{array}$ & [148] \\
\hline $\begin{array}{c}\text { Mogi Guaçu River, São Paulo, } \\
\text { Brazil }\end{array}$ & Surface Water-River & $\mathrm{LC}$ & $\begin{array}{c}\text { MP: } 0-27,500 \\
\text { EP: }<800-30,500 \\
\text { PP: }<500-52,100 \\
\text { BuP: }<800-19,900\end{array}$ & {$[147,149]^{\mathrm{a}}$} \\
\hline
\end{tabular}

${ }^{\mathrm{a}}$ —range based on different samples from different places of the same location; ${ }^{\mathrm{b}}$ —only shows mean values; ${ }^{\mathrm{c}}$-range based on samples of different months.

As can be seen, several studies reported the existence of parabens in different water sources from several locations worldwide, including in drinking and tap water. Together with the parabens detected in effluents composition in Section 5.1.1, it is possible to confirm that WWTPs are not completely efficient in paraben elimination and their emission into the environment leads to accumulation of parabens in these sources, achieving disturbing values and enhancing a visible environmental pollution problem, with different consequences for ecosystems and their living species. It is also possible to conclude that the current legislation is not extensive enough to avoid this problem. 


\subsection{Detection in Humans}

Parabens are also being detected in humans with several and different risks to their lives.

In humans, parabens have been detected in urine [150,151], tumors [28], adipose tissue [152], serum [153], amniotic fluid [6], placental tissues [15,154], breast milk [155], hair [156] and fingernails [129]. The use of personal care products (pharmaceuticals and cosmetics) is the main pathway for the exposure to parabens [20,34], since these types of compounds are present in the composition of daily basis products that can be used for skin, hair, head scalp, lips, mucosae (oral, ocular, and vaginal), axillae and nails [22].

Soni et al. [22] estimated an exposure to propylparaben of $76 \mathrm{mg} /$ day or $1.3 \mathrm{mg} / \mathrm{kg} / \mathrm{day}$ $(1 \mathrm{mg} /$ day for food, $50 \mathrm{mg} /$ day for cosmetics and personal care products and about $25 \mathrm{mg} /$ day for pharmaceuticals). Additionally, Soni et al. [21] estimated a value of $77.5 \mathrm{mg} /$ day or $1.29 \mathrm{mg} / \mathrm{kg} /$ day (considering food at $2.5 \mathrm{mg} /$ day, cosmetics, and personal care products at about $50 \mathrm{mg}$ /day and drugs at $25 \mathrm{mg}$ /day) for total paraben consumption, what can be transformed into $51.6 \mathrm{mg} /$ day and $0.86 \mathrm{mg} / \mathrm{kg} /$ day for just methylparaben [21]. Soni et al. [19] find a consumption of $0.6(0.01 \mathrm{mg} / \mathrm{kg} /$ day $)$ and $0.78 \mathrm{mg} /$ day $(0.013 \mathrm{mg} / \mathrm{kg} /$ day) for MP and PP, respectively, based on FDA data; these values are higher than the FEMA Possible Average Daily Intake (PADI) for these compounds in food products. For cosmetics and pharmaceuticals, values of 0.833 and $0.417 \mathrm{mg} / \mathrm{kg} /$ day have been estimated, respectively, so the total paraben consumption is predicted to be $75.78 \mathrm{mg} /$ day or $1.26 \mathrm{mg} / \mathrm{kg} /$ day [19].

Several laboratory studies have already been carried out to understand the effect of parabens in human organisms, their metabolization and their excretion, as is possible to see in Table 6.

Table 6. Detection, metabolization and extraction of parabens in humans.

\begin{tabular}{ccc}
\hline Parabens(s) & Administration Route & Results \\
\hline PP & Oral $(2 \mathrm{~g})$ & $\begin{array}{c}17.4 \%, 13.7 \%, 3.7 \% \text { and } 55 \% \text { were excreted as p-hydroxybenzoic } \\
\text { acid, free glycine and pair glycine and paired with sulfuric } \\
\text { acid, respectively. }\end{array}$ \\
PP was not found in urine.
\end{tabular}

Barr et al. [56] studied the existence of five parabens at four different locations across the human breast from axilla to sternum, using human breast tissue collected from 40 mastectomies for primary breast cancer. The median values detected were 16.8, 16.6, 5.8, 3.4 and $2.1 \mathrm{ng} / \mathrm{g}$ of tissue, for n-PP, MP, n-BuP, EP and iso-BuP, respectively. The PP was detected in higher concentrations in the axilla than the mid breast (or upper outer quadrants) compared to other parabens.

Schlumpf et al. [155] detected the presence of parabens in human milk, with mean values of $2.18,1.26$ and $1.42 \mathrm{ng} / \mathrm{mL}$ and median values of $1.00,1.30$ and $1.50 \mathrm{ng} / \mathrm{mL}$ for $\mathrm{MP}, \mathrm{EP}$ and n-PP, respectively, and their presence was detected in $15-34 \%$ of the defatted milk samples. BuP was not found.

Casas et al. [158] detected the presence of parabens in urine of pregnant women and 4-year-old boys from Spain, at median concentrations of 191, 8.8, 29.8 and 2.4 ng/mL for 
MP, EP, n-PP and n-BuP, respectively, for pregnant women, and levels of 150, 8.1, 21.5 and 1.2 MP, EP, n-PP and n-BuP, respectively, for the 4-year-old boys.

Guo et al. [151] detected the presence of parabens in the urine of 3-years-old children, where the dominant parabens were MP, EP and PP at median values of 6.03, 3.17 and $2.40 \mu \mathrm{g} / \mathrm{L}$, respectively. BuP and BeP were also found at 0.03 and $0.09 \mu \mathrm{g} / \mathrm{L}$ and the median values of estimated daily intake of five urinary paraben concentrations were 12.10, $5.68,4.50,0.06$ and $0.17 \mu \mathrm{g} / \mathrm{kg}$ of body weight/day for MP, EP, PP, BuP and BeP, respectively.

Silveira et al. [150] analyzed urine samples from Brazilian children aged between 6 and 14 years, and detected geometric mean values of $42.5,0.5,4.22$ and $0.28 \mathrm{ng} / \mathrm{mL}$ for MP, EP, $\mathrm{PP}$ and BuP, respectively. Moreover, the authors detected about 2.65 and $0.48 \mathrm{ng} / \mathrm{mL}$ of paraben metabolites, methyl protocatechuate (OH-MP) and ethyl protocatechuate $(\mathrm{OH}-$ $\mathrm{EP})$, respectively. MP, EP, PP and BuP ranged from 3.21 to $982,<0.10-28.6,<0.03-92.6$ and $<0.03-6.75 \mathrm{ng} / \mathrm{mL}$, respectively. The authors suggest that the wide ranges identified could be related to the exposure of endocrine disruptors and individual factors such as metabolism, so it is possible that a correlation exists between urinary levels of ED and the consumption of personal care products.

Jurewicz et al. [71] studied the influence of urinary parabens on male reproductive problems, detecting geometric mean values of parabens in urine of 14.7, 1.0, 4.3, 0.3 and $0.4 \mu \mathrm{g} / \mathrm{L}$ and median values of 15.6, 9.39, 3.7, 3.48 and $2.27 \mu \mathrm{g} / \mathrm{L}$ for MP, EP, PP, BuP and i-BuP, respectively.

Kolatorova Sosvorova et al. [159] studied the presence of parabens and other compounds in human plasma, and detected median levels of $0.52,0.36$ and $0.56 \mathrm{ng} / \mathrm{mL}$ for MP, $\mathrm{EP}$ and PP, respectively.

Iribarne-Durán et al. [160] studied the presence of parabens and benzophenones in menstrual blood of Spanish women, and detected mean values of 3.19, 0.89, 1.15 and $0.45 \mathrm{ng} / \mathrm{mL}$ for MP, EP, PP and BuP, respectively. Additionally, they detected median levels of $1.41,0.40,0.63$ and 0.37 for the same order of parabens. From samples of 57 women, all the samples presented the existence of three or more of the studied compounds, and $52.6 \%$ of samples had six or more of these compounds. The most detected paraben was MP in $98.2 \%$ of samples and the lowest one was BuP in $56.2 \%$ of samples.

Ye et al. [153] detected parabens in human serum at mean values of $42.6 \mathrm{ng} / \mathrm{mL}$ for $\mathrm{MP}$ and $7.4 \mathrm{ng} / \mathrm{mL}$ for PP, and median concentrations of 10 and $1.2 \mathrm{ng} / \mathrm{mL}$ for $\mathrm{MP}$ and $\mathrm{PP}$, respectively.

Zhang et al. [161] detected the presence of parabens and their metabolites in urine and blood samples from 196 Chinese university students. MP appeared in $68 \%$ and $52 \%$ of urine and blood samples, and the 4-HB was the predominant paraben metabolite, detected in $54 \%$ and $41 \%$ of urine and blood samples, respectively. The mean values for urine samples were 15.4, 4.76, 7.82, 0.4, 21.3, 0.84, 182 and $288 \mathrm{ng} / \mathrm{mL}$ for MP, EP, PP, BuP, OH-MP, OH-EP, 3,4-dihydroxybenzoic acid (3,4-DHB) and 4-hydroxybenbzoic acid (4-HB), respectively. For the same compound order, but regarding blood samples, the mean values were 1.60, 0.81 , $0.85,0.88,1.95,0.65,2.29$, and $4.01 \mathrm{ng} / \mathrm{mL}$. The geometric mean values were 8.01, 0.25, 3.22, $0.24,10.1,0.25,86.2$ and $129 \mathrm{ng} / \mathrm{mL}$ for MP, EP, PP, BuP, OH-MP, OH-EP, 3,4-DHB and $4-\mathrm{HB}$, respectively, regarding urine samples, and for blood samples, the geometric mean values were $0.33,0.05,0.24,0.06,0.25,0.06,0.36$ and $1.26 \mathrm{ng} / \mathrm{mL}$. Additionally, the median values in urine were $9.88,1.11,3.23,0.24,11.3,0.24,115$ and $167 \mathrm{ng} / \mathrm{mL}$ and, in blood samples were $0.84,0.17,0.70,<0.02,1.06,0.19,1.67$ and 2.88 for MP, EP, PP, BuP, OH-MP, $\mathrm{OH}-\mathrm{EP}, 3,4-\mathrm{DHB}$ and 4-HB, respectively. The EDI median values for university students were $25.9,1.61$ and $3.82 \mu \mathrm{g} / \mathrm{kg}$ body weight/day, and these values were higher in females than in males.

Guth et al. [72] tested 382 urine samples and serum hormone concentrations of young girls aged 6-17 years old and living in Canada. The geometric mean values were 11.2 and $1.9 \mu \mathrm{g} / \mathrm{L}$ for MP and PP, while for EP and BuP values were below the limit of detection. The median values were 9.7, $<\mathrm{LOD}, 1.4$ and $<\mathrm{LOD}$ for MP, EP, PP and BuP, respectively. 
Hines et al. [162] studied the presence of parabens and other compounds in urine, human milk, and human serum from 34 women from North Carolina. MP was detected in almost every sample in all matrices and in all visits, and parabens were detected in most milk samples, but none of the milk samples showed detectable values of BuP. The highest individual concentration values for MP were 2.3, 40.1 and $75.3 \mu \mathrm{g} / \mathrm{L}$ for milk, serum, and urine, respectively, and regarding PP, the values were $0.6,5.4$ and $279 \mu \mathrm{g} / \mathrm{L}$ for the same sample matrices order. Other parabens, such as EP and BuP, and other compounds, were also detected. The highest median values for MP and PP were 3.35 and $0.9 \mu \mathrm{g} / \mathrm{L}$ regarding serum and 143, 5.3, 41.3 and $2.9 \mu \mathrm{g} / \mathrm{L}$, for MP, EP, PP and BuP.

Van Overmeire et al. [154] analyzed human placenta samples for the detection of parabens, bisphenols, alkylphenols and tert-octylphenol. The mean values were $4.3,0.7$ and $1.0 \mathrm{ng} / \mathrm{g}$ for MP, EP and PP, respectively, and the median values were $4.4,0.7$ and $1.0 \mathrm{ng} / \mathrm{g}$ for the same parabens.

Wang et al. [152] analyzed 20 human adipose fat tissue from people from New York City, and the geometric mean values of parabens were 0.895 and $0.488 \mathrm{ng} / \mathrm{g}$ wet weight for $\mathrm{EP}$ and $\mathrm{PP}$, respectively, since for $\mathrm{MP}, \mathrm{BuP}, \mathrm{HeP}$ and $\mathrm{BzP}$ the values were not calculated due to the detection frequency being below $50 \%$. The p-hydroxybenzoic acid, a metabolite of parabens, was detected to a geometric value of $4160 \mathrm{ng} / \mathrm{g}$ wet weight.

C. Li et al. [129] studied the presence of parabens in 50 human fingernails of participants from Nanjing, China, and the geometric mean values were 2070, 136, 785, 17.9, 1.48, $0.02 \mathrm{ng} / \mathrm{g}$ for MP, EP, PP, BuP, BeP and HeP, respectively, while in the case of paraben metabolites, the values found were $0.12,0.09$ and $18.2 \mathrm{ng} / \mathrm{g}$ for 4-HB, OH-EP and OH-MP. The calculated median levels were 2070, 785, 136, 17.9, 1.48, 0.02, 0.12, 0.09 and 18.2 for MP, EP, PP, BuP, BeP, HeP, 4-HB, OH-EP and OH-MP. The female fingernails contained higher values of parabens and metabolites than male fingernails, which can be explained by the greater use of personal care products by females.

Tkalec et al. [163] determined parabens among children (6-9 years old) and adolescents (11-15 years old) from Slovenia by analyzing their urine and detected mean values of 23 , 9.1 and $5.6 \mu \mathrm{g} / \mathrm{L}$ for MP, EP and PP and median levels of 5, 2.7, 0.13, 0.21 and $0.15 \mu \mathrm{g} / \mathrm{L}$ for $\mathrm{MP}, \mathrm{EP}$, i-PP, $\mathrm{PP}$ and $\mathrm{BuP}$ regarding children, while regarding adolescents the values were 20, 12 and $1.4 \mu \mathrm{g} / \mathrm{L}$ for MP, EP and PP, and the median values were 5, 4.4, 0.13, 0.22 and 0.15 for MP, EP, i-PP, PP and BuP, respectively. Other parabens were detected but were under the limit of quantification.

Martín et al. [156] detected endocrine disruptor compounds by analyzing hair samples from children and adults, concluding that all the pollutants were found in the hair samples, where the parabens predominated. The detected mean values in the hair samples were 2820.7, 634.8 and $1006.1 \mathrm{ng} / \mathrm{g}$ for MP, EP and PP, respectively, and the detected median values were 822.1, 47.2 and $256.3 \mathrm{ng} / \mathrm{g}$ for MP, EP and PP. The concentration of parabens was higher in adults than in children.

\subsection{Detection in Animals}

The detection of parabens in other organisms such as animals is a current concern for some authors, due to the negative impacts they have on lives and their existence.

Some studies showed complete absorption of methylparaben and propylparaben by the gastrointestinal tract, with full metabolization and excretion for rats, rabbits, dogs, and cats. The introduction of parabens via skin absorption also occurs and can reach approximately $100 \%$ [21,22]. However, the major metabolites found in urine are p-hydroxybenzoic acid, glycine acid, glucuronic acid, and sulfuric acid, since propylparaben or their metabolites are not accumulated in the body or detected in urine [21,22]. This paraben is ingested and metabolized in the liver and kidneys, and only a small quantity of PP appears in feces within 5 to $72 \mathrm{~h}$ in the form of p-hydroxybenzoic acid or its conjugates [22].

Table 7 presents the results of different studies on the detection, metabolization and excretion of parabens at different concentrations, from different administration routes and for different animals. 
Table 7. Detection, metabolization and extraction of parabens in humans.

\begin{tabular}{|c|c|c|c|c|}
\hline Parabens(s) & Animal & $\begin{array}{l}\text { Administration } \\
\text { Route }\end{array}$ & Results & Reference \\
\hline $\begin{array}{c}\text { MP } \\
\text { EP } \\
\text { PP } \\
\text { BuP }\end{array}$ & Dogs & $\begin{array}{c}\text { Intravenous } \\
(50 \mathrm{mg} / \mathrm{kg}) \\
\text { Oral }(1 \mathrm{~g} / \mathrm{kg})\end{array}$ & $\begin{array}{l}\text { Blood and urine analyzed. } \\
\text { Very low quantity remained in the blood after } \\
\text { administration, but p-hydroxybenzoic acid was detected } \\
\text { in blood. } \\
\text { In } 100 \mathrm{mg} / \mathrm{kg} \text { of MP and PP administered intravenously, } \\
\text { the ester was only detected in brain, spleen, and pancreas, } \\
\text { but high concentrations of metabolites were detected in } \\
\text { kidneys and liver. } \\
\text { By oral administration of } 1 \mathrm{~g} / \mathrm{kg} / \text { day for } 1 \text { year, the } \\
\text { existence of accumulation of MP or PP was not verified, and } \\
66 \% \text { and } 96 \% \text { of these doses of MP and PP, respectively, } \\
\text { were excreted daily in urine. } \\
\text { Of the } 66 \% \text { of MP excreted, } 21 \% \text { was as p-hydroxybenzoic } \\
\text { acid and } 33 \% \text { was as glucuronic acid conjugates. } \\
\text { The recovery of all parabens was between } 58 \% \text { and } 94 \% \text {, } \\
\text { except for BuP which was } 40-48 \% \text {. }\end{array}$ & {$[19,21,22,164]$} \\
\hline
\end{tabular}

$39 \%$ of MP was excreted as p-hydroxybenzoic acid, $15 \%$ as glycine, $7 \%$ and $15 \%$ as glucuronic acid ester and ether, and $10 \%$ as sulfuric acid.

$30 \%$ of the dose of propylparaben was excreted as p-hydroxybenzoic acid, $24 \%$ as glycine, $7 \%$ and $13 \%$ as glucuronic acid ester and ether, and $7 \%$ as sulfuric acid.

MP

EP

PP

$\mathrm{BuP}$

Rabbits

Oral

(0.4 or $0.8 \mathrm{~g} / \mathrm{kg})$

The excretion rate of $0.8 \mathrm{~g} / \mathrm{kg}$ was quicker than $0.4 \mathrm{~g} / \mathrm{kg}$, and about $70 \%$ of $0.4 \mathrm{~g} / \mathrm{kg}$ was excreted in $9 \mathrm{~h}, 86 \%$ in $24 \mathrm{~h}$ and $88 \%$ in $48 \mathrm{~h}$.

Oral administration of parabens resulted in excretion of $0.2-0.9 \%$ of the unchanged ester by $24 \mathrm{~h}$.

As the length of the alkyl chain increased, the rate of urinary excretion decreased, so, in general, after $24 \mathrm{~h}$, $25-39 \%$ was excreted as p-hydroxybenzoic acid, $25-29 \%$ as the glycine conjugate, $5-8 \%$ and $10-18 \%$ as ester and ether glucuronide, respectively, and $7-12 \%$ as sulfate.

Quick absorption by gastrointestinal tract and easy hydrolyzation into p-hydroxybenzoic acid in different organs.

30 min after administration, paraben metabolites were detected in urine, and 90 min after the maximum excretion of the metabolites was observed.

$\mathrm{MP}$

EP

PP

Rats

Oral (100 mg)

\section{P-hydro}

win acid was detected in urine after $30 \mathrm{~min}$ with an increase in concentration for the next $4 \mathrm{~h}$.

$[19,21,22,168]$

After $90 \mathrm{~min}$, about $67-75 \%$ of the total paraben dose was excreted as p-hydroxybenzoic acid, and 8-9\% as glucuronyl derivatives.

The concentration of parabens or benzoic acid in blood was extremely low.
For urine, at 24 and $72 \mathrm{~h}$, about $90 \%$ and $95.6 \%$ of the dose was excreted, respectively, and $6 \%$ and $3 \%$ in feces at $24 \mathrm{~h}$,

$\begin{array}{llc}\text { EP } & \text { Cral } & \text { Oral } \\ \mathrm{PP} & (158 \mathrm{mg} / \mathrm{kg})\end{array}$

for EP and PP, respectively.
The two major metabolites were p-hydroxyhippuric acid and p-hydroxybenzoic acid.

After $72 \mathrm{~h}$ post oral administration, the PP was 
Table 7. Cont.

\begin{tabular}{cccc}
\hline Parabens(s) & Animal & $\begin{array}{c}\text { Administration } \\
\text { Route }\end{array}$ & Results \\
\hline $\begin{array}{c}\text { Other } \\
\text { parabens }\end{array}$ & Frogs & $\begin{array}{c}\text { Dermal } \\
\text { absorption }\end{array}$ & $\begin{array}{c}\text { Paraben adsorption was higher for longer chain and fastest } \\
\text { during the first } 20 \text { min. }\end{array}$ \\
\hline $\begin{array}{c}\text { MP } \\
\text { PP }\end{array}$ & Rats & Oral & For $1 \mathrm{~g} / \mathrm{kg} /$ day of MP and PP in 1 year, about 96-100\% was \\
excreted daily.
\end{tabular}

Parabens (MP, EP, PP and BuP) have also been found in fishes in Manila Bay, the Philippines, ranging from 605 to $3450 \mathrm{ng} / \mathrm{g}$ lipid weight (glw) for MP, 46.6 to $195 \mathrm{ng} / \mathrm{glw}$ for EP, 46 to $1140 \mathrm{ng} / \mathrm{glw}$ for PP and 6.61-37.3 ng/glw for BuP [172]. In another study at the same bay, MP, PP and BuP were found in more than $90 \%$ of fish samples and EP in $70 \%$, from 58 fish of 20 different species collected in the local market. The MP was predominant in muscle tissues and was detected at $<0.05-3600 \mathrm{ng} / \mathrm{glw},<0.011-840 \mathrm{ng} / \mathrm{glw}$ for EP, $<0.024-110 \mathrm{ng} / \mathrm{glw}$ for PP and $<0.003-70 \mathrm{ng} / \mathrm{glw}$ for BuP [173]. These studies lead to the conclusions that parabens are constant contaminants of fish and are present in the marine coast of Philippines [17]. In Spain, an analysis of 50 fish from different species allowed the detection of parabens at $84.69 \mathrm{ng} / \mathrm{g}$ dry weight (gdw) for MP and $0.19 \mathrm{ng} / \mathrm{gdw}$ for PP. MP was present in $46 \%$ of samples and $\mathrm{BeP}$ in $22 \%$, although their quantity was not possible to quantify [167]. Additionally, the highest values of MP and PP were found in Salmo trutta fish, in a river impacted by effluents because it is near to an urban wastewater treatment plant that serves about 57,032 habitants [174].

A study carried out by Xue et al. [175] tested the presence of six parabens (MP, EP, $\mathrm{PP}, \mathrm{BuP}, \mathrm{BeP}$ and Heptylparaben (HeP)) and four metabolites (4-hydroxybenbzoic acid (4-HB), 3,4-dihydroxybenzoic acid (3,1-DHB), methyl protocatechuate (OH-MeP) and ethyl protocatechuate (OH-EP)) in 121 tissue samples from eight species of marine mammals (pygmy sperm whale, clymene dolphin, rough-toothed dolphin, striped dolphin, bottlenose dolphin, southern sea otter, norther sea otter and polar bear) from the coastal waters of Florida, California, Washington and Alaska.

For the Florida coast, the livers and the blubber of dolphins and whales from different spots were analyzed, indicating the presence of MP as the predominant paraben and 4-HB as the predominant metabolite, and $\mathrm{PP}, \mathrm{OH}-\mathrm{MeP}$ and 3,4-DHB were also found in $5-25 \%$ of the samples, at mean values (in liver) of $188,74.5,98.0,120,<41.1$ and $31.4 \mathrm{ng} / \mathrm{g}$ wet weight regarding MP for bottlenose dolphin, striped dolphin, rough-toothed dolphin, clymene dolphin and pygmy sperm whale, respectively, and obtaining mean values (in liver) of 7980, 4230, 8620, 11900, 1450, $2520 \mathrm{ng} / \mathrm{g}$ wet weight for the same order of species for 4-HB [175].

Regarding the California coast, the livers, brains, and kidneys of southern sea otters were analyzed, achieving MP mean values (in liver) of 30.9, 22.4, and $23.4 \mathrm{ng} / \mathrm{g}$ wet weight for males, and 33.2, 56.9 and $<10.26 \mathrm{ng} / \mathrm{g}$ wet weight for females located in different spots of the California coast. The values obtained by kidney analysis were 121, 41.9 and $84.5 \mathrm{ng} / \mathrm{g}$ wet weight for males and $12.2 \mathrm{and} 152 \mathrm{ng} / \mathrm{g}$ wet weight for females in different spots, and a brain analysis uncovered the mean values of $27.1,18.8$ and $14 \mathrm{ng} / \mathrm{g}$ wet weight for males and $6.80 \mathrm{ng} / \mathrm{g}$ wet weight for females. Regarding 4-HB for this coast, mean values of detection in liver were 16,800, 7330 and $7930 \mathrm{ng} / \mathrm{g}$ wet weight for males and $17,200,19,600$ and $5690 \mathrm{ng} / \mathrm{g}$ wet weight for females; the detection values in kidneys were $23,800,7980,2480 \mathrm{ng} / \mathrm{g}$ wet weight for males and 3580 and 33,000 ng/g wet weight for females, while for brain analysis the values were 3240, 1610 and $458 \mathrm{ng} / \mathrm{g}$ wet weight for males and 1590 for females [175]. 
In Washington coast, the species under analysis was the northern sea otter and the detection values for MP were 92.4 and $95.2 \mathrm{ng} / \mathrm{g}$ wet weight for males and females, respectively, and 6890 and 12,900 ng/g wet weight for males and females regarding 4-HB. For the Alaskan waters, polar bears and northern sea otter samples were analyzed, detecting values of around 197 and $21.8 \mathrm{ng} / \mathrm{g}$ wet weight of MP for males and nonidentified sex for sea otters, and 4.57 and $7.30 \mathrm{ng} / \mathrm{g}$ wet weight for male and female polar bears, and for 4-HB values were 5160, 1520, 395 and $569 \mathrm{ng} / \mathrm{g}$ wet weight for the same sequence of species [175].

Xue et al. [176] studied the presence of six parabens and their metabolites in 254 tissue samples (liver, kidney, egg, and plasma) of 12 species of fish and seven species of birds, and the liver and kidney tissues of black bears were also analyzed. Fishes were from Michigan waters (including Great Lakes), New York waters and the Florida coast, while birds were from the Baltic Sea coast, Midway Atoll, Great Lakes region and other locations.

Regarding fish from Michigan and Great Lakes, only MP was found in some fish samples, and 4-HB was the major metabolite detected, for mean values of $55.8 \mathrm{ng} / \mathrm{g}$ wet weight of 4-HB at Siskiwit Lake from Lake trout species, since this was the only compound in high enough quantities to be quantified. For New York waters, the detection and quantification of MP yielded mean values of 173 and $85.0 \mathrm{ng} / \mathrm{g}$ wet weight, while for 4-HB the values were 873,6530, 127, 8690 and $151 \mathrm{ng} / \mathrm{g}$ wet weight, for different tissues and fish species under analysis [176].

For the Florida coast and black bears from Michigan, the values detected were 43.8, $44.3 \mathrm{ng} / \mathrm{g}$ wet weight, from liver, and <2.01, $13.6 \mathrm{ng} / \mathrm{g}$ wet weight from muscle for MP, 13.2 and $48.3 \mathrm{ng} / \mathrm{g}$ wet weight of PP from liver and muscle; additionally, 575 and $1130 \mathrm{ng} / \mathrm{g}$ wet weight from liver, and $<20.2$ and $33.9 \mathrm{ng} / \mathrm{g}$ wet weight of 4-HB from muscle were detected for striped mullet females, while for red drum, the MP values were 22.7 and $38.1 \mathrm{ng} / \mathrm{g}$ wet weight for liver samples and <2.01 and $2.26 \mathrm{ng} / \mathrm{g}$ wet weight for muscle from a male specimen and a $11.2 \mathrm{ng} / \mathrm{g}$ wet weight for the female's liver sample. As for PP, the values were 5.14 and $24.8 \mathrm{ng} / \mathrm{g}$ wet weight for male liver and $9.06 \mathrm{ng} / \mathrm{g}$ wet weight for female liver, and for 4-HB the reported values were 412, $434 \mathrm{ng} / \mathrm{g}$ wet weight for male liver and $659 \mathrm{ng} / \mathrm{g}$ wet weight for female liver. Regarding shark liver, muscle, kidney, gill and brain samples, the values were 13, 43.9, 18.8, 71 and $735 \mathrm{ng} / \mathrm{g}$ wet weight for MP, 3.61, $10.4,4.9,6.26$ and $8.07 \mathrm{ng} / \mathrm{g}$ wet weight for PP and 17.6, 25.7, 1120, 380 and $283 \mathrm{ng} / \mathrm{g}$ wet weight for 4-HB, while for the black bears, for liver and kidneys, the values were 33.5, 58.2, 24.0 and $37.6 \mathrm{ng} / \mathrm{g}$ wet weight of MP for liver and kidneys (two values each, respectively), 107, 2480, 66.1 and $653 \mathrm{ng} / \mathrm{g}$ wet weight of HeP for the same order and also 985, 2460, 823 and $1820 \mathrm{ng} / \mathrm{g}$ wet weight for 4-HB [176].

Regarding samples of birds from Midway Atoll, Great Lakes region and other locations, the mean values for sea eagle liver were 112 and 11,500 ng/g wet weight of MP and 4-HB, respectively, for black-footed albatross liver and kidney values were 10.3 and 9.55 for MP and 362 and $2350 \mathrm{ng} / \mathrm{g}$ wet weight for 4-HB, and for bald eagle, MP and 4-HB were only quantified in plasma at 0.09 and $28.6 \mathrm{ng} / \mathrm{g}$ wet weight, respectively. For herring gull eggs, MP was detected at values of 4.63 and $4-\mathrm{HB}$ at $89.4 \mathrm{ng} / \mathrm{g}$ wet weight, while for common cormorant, only $4-\mathrm{HB}$ was detected at $73.8 \mathrm{ng} / \mathrm{g}$ wet weight. Liver and egg samples of loon showed mean values of 43.2 and $3.80 \mathrm{ng} / \mathrm{g}$ wet weight, respectively, for MP, and 8580 and $285 \mathrm{ng} / \mathrm{g}$ wet weight, for 4-HB. The Laysan albatross presented detectable values of MP in kidney and muscle at 6.10 and $5.48 \mathrm{ng} / \mathrm{g}$ wet weight, respectively, while regarding $4-\mathrm{HB}$, the liver, kidney, brain, fat, and muscle samples detected 4 -HB at 531, 753, $66.8,39.8$ and $155 \mathrm{ng} / \mathrm{g}$ wet weight, respectively [176]. In all these studies, some values that were not quantified or detectable, which is shown in the range of values when the compounds were detected in only one or two measures.

Figure 3 shows the geographic locations which parabens were found in animals. 


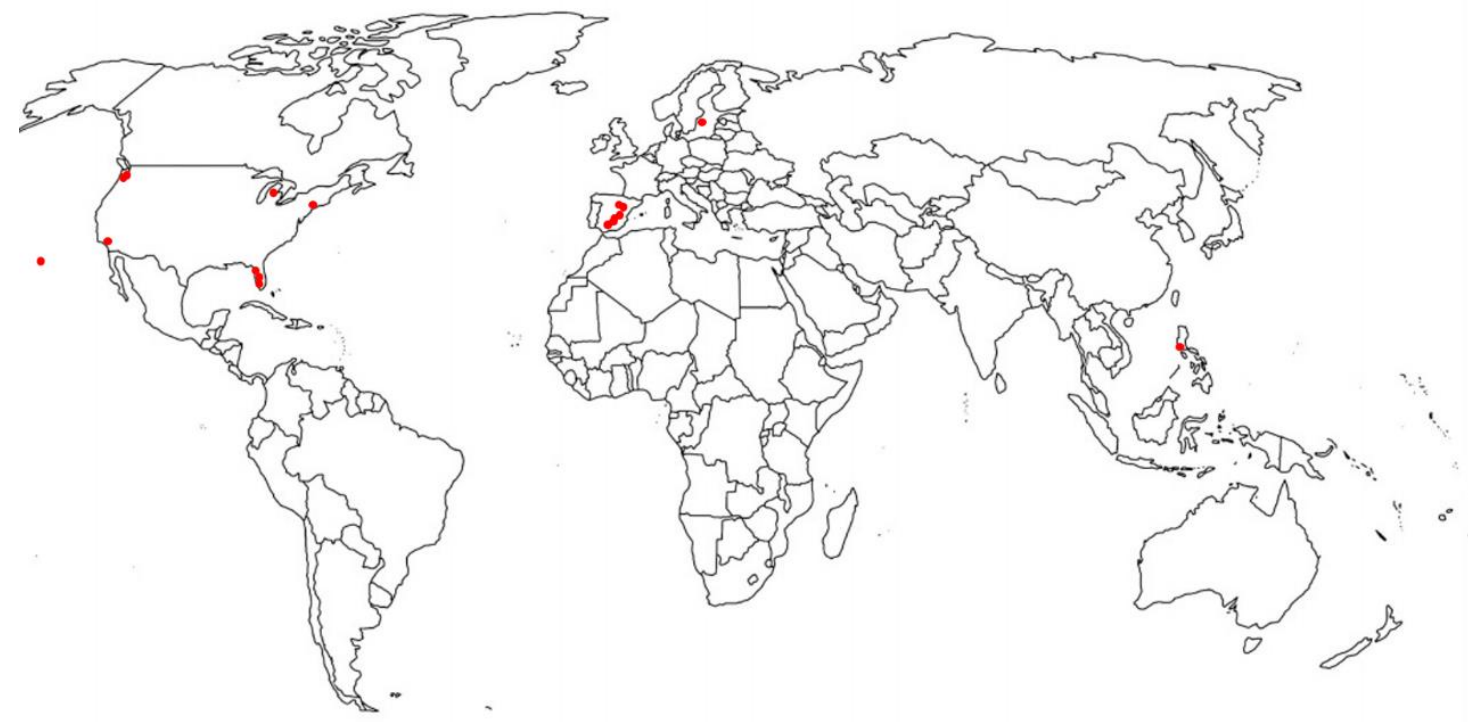

Figure 3. Geographic locations of animals which parabens were found.

\section{Conclusions}

This work reviews the role of parabens in daily life and analyzes paraben characteristics, properties, detections in various sources and organisms, toxicological studies, dangers for humans and animals, legislation, and regulations.

Parabens are widely used in different applications due to the wide range of their characteristics which render these products suitable solutions. However, as mentioned, the impact of these compounds for human health can be problematic. Nevertheless, parabens were already detected in different tissues, organs, and human fluids, in great part due to the usage of pharmaceuticals and personal care products. In fact, the increase in consumption of such products promotes higher release in domestic wastewaters. Moreover, these compounds have been widely detected in different water sources. This presence indicates that the conventional methods cannot be used as effective treatment technology for their abatement. So, it is possible to conclude that parabens are being discovered in several sources and organisms worldwide.

The impact on animals, especially in aquatic species, can be worrying, since several species can suffer different negative impacts, mainly related to parabens disrupting endocrine behaviour. Some of the reported studies show that they can affect the reproductive systems of animals, decreasing their population and also inducing other related problems in terms of the species' health. The impact on ecosystems is difficult to measure, but other species can be affected, since it is reported that invertebrates such as D. magna play an important role in aquatic ecosystems, mainly because this species is a key in food resources for others aquatic animals, and the presence of parabens negatively decreases the chances of survival of species.

In general, it is possible to conclude that the legislation regarding the use of parabens in industries are being changed and updated, and currently, the use of some parabens is forbidden or under severe restrictions. Regarding water discharges or paraben detection in ecosystems, EU legislation does not include them in the watchlist of substances to be monitored and does not classify parabens as "water pollutants". Further studies are required to unravel the true role of parabens in human health and ecosystems so that adequate regulation may be enforced. Moreover, suitable treatment technologies must be developed to remove such persistent compounds from wastewaters before discharge in order to protect the environment.

Author Contributions: Conceptualization, J.G. and R.C.M.; methodology, J.L.; investigation, J.L., R.C.M. and J.G. data curation, J.L.; writing—original draft preparation, J.L.; writing—review and 
editing, J.G. and R.C.M.; supervision, J.G. and R.C.M. All authors have read and agreed to the published version of the manuscript.

Funding: This work was financially supported by Fundação para a Ciência e Tecnologia (FCT-MEC), Portugal under contracts UID/EQU/00102/2019. The authors gratefully acknowledge Foundation for Science and Technology_FCT (Portugal) by the financial support (CEECIND/01207/2018).

Institutional Review Board Statement: Not applicable.

Informed Consent Statement: Not applicable.

Data Availability Statement: Not applicable.

Conflicts of Interest: The authors declare no conflict of interest.

\section{References}

1. Li, W.; Gao, L.; Shi, Y.; Wang, Y.; Liu, J.; Cai, Y. Spatial distribution, temporal variation and risks of parabens and their chlorinated derivatives in urban surface water in Beijing, China. Sci. Total Environ. 2016, 539, 262-270. [CrossRef]

2. Lin, Y.; Ferronato, C.; Deng, N.; Wu, F.; Chovelon, J. Photocatalytic degradation of methylparaben by TiO2: Multivariable experimental design and mechanism. Appl. Catal. B Environ. 2009, 88, 32-41. [CrossRef]

3. Frontistis, Z.; Antonopoulou, M.; Venieri, D.; Dailianis, S.; Konstantinou, I.; Mantzavinos, D. Solar photocatalytic decomposition of ethyl paraben in zinc oxide suspensions. Catal. Today 2017, 280, 139-148. [CrossRef]

4. Frontistis, Z.; Antonopoulou, M.; Petala, A.; Venieri, D.; Konstantinou, I.; Kondarides, D.I.; Mantzavinos, D. Photodegradation of ethylparaben using simulated solar radiation and Ag3PO4 photocatalyst. J. Hazard. Mater. 2017, 323, 478-488. [CrossRef]

5. Fernandes, R.A.; Sampaio, M.J.; Drazic, G.; Faria, J.L.; Silva, C.G. Efficient removal of parabens from real water matrices by a metal-free carbon nitride photocatalyst. Sci. Total Environ. 2020, 716, 135346. [CrossRef] [PubMed]

6. Xiao, X.; Lu, M.; Nan, J.; Zuo, X.; Zhang, W.; Liu, S.; Wang, S. Rapid microwave synthesis of I-doped Bi4O5Br2 with significantly enhanced visible-light photocatalysis for degradation of multiple parabens. Appl. Catal. B Environ. 2017, 218, 398-408. [CrossRef]

7. Yang, H.; Zhang, F.; Wy, H. Life cycle of parabens: Synthesis, degradation, characterization and safety analysis. Curr. Org. Chem. 2018, 22, 769-779. [CrossRef]

8. Rizzo, L.; Malato, S.; Antakyali, D.; Beretsou, V.G.; Dolic, M.B.; Gernjak, W.; Heath, E.; Ivancev-Tumbas, I.; Karaolia, P.; Lado Ribeiro, A.R.; et al. Consolidated vs new advanced treatment methods for the removal of contaminants of emerging concern from urban wastewater. Sci. Total Environ. 2019, 655, 986-1008. [CrossRef]

9. Tufail, A.; Price, W.E.; Mohseni, M.; Pramanik, B.K.; Hai, F.I. A critical review of advanced oxidation processes for emerging trace organic contaminant degradation: Mechanisms, factors, degradation products, and effluent toxicity. J. Water Process Eng. 2020, 101778. [CrossRef]

10. Vela, N.; Calín, M.; Yáñez-Gascón, M.J.; Garrido, I.; Pérez-Lucas, G.; Fenoll, J.; Navarro, S. Solar reclamation of wastewater effluent polluted with bisphenols, phthalates, and parabens by photocatalytic treatment with TiO2/Na2S2N8 at pilot plant scale. Chemosphere 2018, 212, 95-104. [CrossRef]

11. WWF-World Wildlife. Water Scarcity. 2020. Available online: https:/ /www.worldwildlife.org/threats/water-scarcity (accessed on 1 December 2020).

12. Rizzo, L.; Gernjak, W.; Krzeminski, P.; Malato, S.; McArdell, C.S.; Perez, J.A.S.; Schaar, H.; Fatta-Kassinos, D. Best available technologies and treatment trains to address current challenges in urban wastewater reuse for irrigation crops on EU countries. Sci. Total Environ. 2020, 710, 136312. [CrossRef]

13. Peng, X.; Adachi, K.; Chen, C.; Kasai, H.; Kanoh, K.; Shizuri, Y.; Misawa, N. Discovery of a marine bacterium producing 4-hydroxibenzoate and its alkyl esters, parabens. Appl. Environ. Microbiol. 2006, 72, 5556-5561. [CrossRef]

14. Baardseth, P.; Russwurm, H., Jr. Content of some organic acids in cloudberry (Rubus chamaemorus L.). Food Chem. 1978, 3, 43-46. [CrossRef]

15. Juliano, C.; Magrini, G.A. Cosmetic Ingredients as Emerging Pollutants of Environmental and Health Concern: A Mini-Review. Cosmetics 2017, 4, 11. [CrossRef]

16. Tade, R.S.; More, M.P.; Chatap, V.K.; Deshmukh, P.K.; Patil, P.O. Safety and Toxicity Assessment of Parabens in Pharmaceutical and Food Products. Inventi Rapid Pharm. Pract. 2018, 3, 25655.

17. Haman, C.; Dauchy, X.; Rosin, C.; Munoz, J. Occurrence, fate and behavior of parabens in aquatic environments: A review. Water Res. 2015, 68, 1-11. [CrossRef] [PubMed]

18. Marta-Sanchez, A.V.; Caldas, S.S.; Schneider, A.; Cardoso, S.M.V.S.; Primel, E.G. Trace analysis of parabens preservatives in drinking water treatment sludge, treated, and mineral water samples. Environ. Sci. Pollut. Res. 2018, 25, 14460-14470. [CrossRef] [PubMed]

19. Soni, M.G.; Carabin, I.G.; Burdock, G.A. Safety assessment of esters of p-hydroxybenzoic acid (parabens). Food Chem. Toxicol. 2005, 43, 985-1015. [CrossRef]

20. Francisco, A.; Fonseca, A.P. Parabens paradoxes in cosmetic formulations: A review. International journal of medical research and pharmaceutical sciences. Int. J. Med Res. Pharm. Sci. 2016, 3, 1-11. 
21. Soni, M.G.; Taylor, S.L.; Greenberg, N.A.; Burdock, G.A. Evaluation of the health aspects of methyl paraben: A review of the published literature. Food Chem. Toxicol. 2002, 40, 1335-1373. [CrossRef]

22. Soni, M.G.; Burdock, G.A.; Taylor, S.L.; Greenberg, N.A. Safety assessment of propyl paraben: A review of the published literature. Food Chem. Toxicol. 2001, 39, 513-532. [CrossRef]

23. Liao, C.; Liu, F.; Kannan, K. Occurrence of and Dietary Exposure to Parabens in Foodstuffs from the United States. Environ. Sci. Technol. 2013, 47, 3918-3925. [CrossRef] [PubMed]

24. Liao, C.; Chen, L.; Kannan, K. Occurrence of parabens in foodstuffs from China and its implications for human dietary exposure. Environ. Int. 2013, 57-58, 68-74. [CrossRef]

25. Guo, Y.; Kannan, K. A survey of phthalates and parabens in personal care products from the united states and its implications for human exposure. Environ. Sci. Technol. 2013, 47, 14442-14449. [CrossRef] [PubMed]

26. Nowak, K.; Jablonska, E.; Ratajczak-Wrona, W. Controversy around parabens: Alternative strategies for preservative use in cosmetic and personal care products. Environ. Res. 2020, 110488. [CrossRef]

27. Gomes, J.; Frasson, D.; Pereira, J.L.; Gonçalves, F.J.M.; Castro, L.M.; Quinta-Ferreira, R.M.; Martins, R.C. Ecotoxicity variation through parabens degradation by single and catalytic ozonation using volcanic rock. Chem. Eng. J. 2019, 360, 30-37. [CrossRef]

28. Darbre, P.D.; Aljarrah, A.; Miller, W.R.; Coldham, N.G.; Sauer, M.J.; Pope, G.S. Concentrations of parabens in human breast tumours. J. Appl. Toxicol. 2004, 24, 5-13. [CrossRef]

29. Martins, A.S.; Nuñez, L.; Vasconcelos Lanza, M.R. Enhanced photoelectrocatalytic performance of $\mathrm{TiO}_{2}$ nanotube array modified with WO3 applied to the degradation of the endocrine disruptor propyl paraben. J. Electroanal. Chem. 2017, 802, 33-39. [CrossRef]

30. Soler de la Vega, A.C.; Molins-Delgado, D.; Barceló, D.; Díaz-Cruz, M.S. Nanosized titanium dioxide UV filter increases mixture toxicity when combined with parabens. Ecotoxicol. Environ. Saf. 2019, 184, 109565. [CrossRef]

31. Terasaka, S.; Inoue, A.; Tanji, M.; Kiyama, R. Expression profiling of estrogen-responsive genes in breast cancer cells treated with alkylphenols, chlorinated phenols, parabens, or bis- and benzoylphenols for evaluation of estrogenic activity. Toxicol. Lett. 2006, 163, 130-141. [CrossRef]

32. Chen, J.; Ahn, K.C.; Gee, N.A.; Gee, S.J.; Hammock, B.D.; Lasley, B.L. Antiandrogenic properties of parabens and other phenolic containing small molecules in personal care products. Toxicol. Appl. Pharmacol. 2007, 221, 278-284. [CrossRef] [PubMed]

33. Tavares, R.S.; Martins, F.C.; Oliveira, P.J.; Ramalho-Santos, P.; Peixoto, F.P. Parabens in male infertility-Is there a mitochondrial connection? Reprod. Toxicol. 2009, 27, 1-7. [CrossRef]

34. Bledzka, D.; Gromadzinska, J.; Wasowicz, W. Parabens. From environmental studies to human health. Environ. Int. 2014, 67, 27-42. [CrossRef]

35. Sabalitschka, T.; Neufeld-Crzelliter, R. Behavior of p-hydroxybenzoic acid in human body. Arzneimittel-Forschung 1954, 4, 575-579, (cited in Soni et al. 2001).

36. Braccesi, M.A. Antiseptic properties of derivative of salicylic acid: Methyl ester of p-hydroxybenzoic acid. Bolletino Soc. Ital. Di Biol. Sper. 1939, 14, 289-290, (cited in Soni et al. 2001).

37. Elder, R.L. Final report on the safety assessment of methylparaben, ethylparaben, propylparaben and butylparaben. J. Am. Coll. Toxicol. 1984, 3, 147-209, (cited in Soni et al. 2005).

38. Sokol, H. Recent developments in the preservations of pharmaceuticals. Drug Stand. 1952, 20, 89-106, (cited in Soni et al. 2001, 2002, 2005).

39. Bao-Liang, S.; Hai-Ying, L.; Dun-Ren, P. In-vitro spermicidal activity of parabens against human spermatozoa. Contraception 1989, 39, 331-336, (cited in Soni et al. 2001, 2002, 2005). [CrossRef]

40. Adoamnei, E.; Mendiola, J.; Monino-García, M.; Vela-Soria, F.; Iribarne-Durán, L.M.; Fernández, M.F.; Olea, N.; Jorgensen, N.; Swan, S.H.; Torres-Cantero, A.M. Urinary concentrations of parabens and reproductive parameters in young men. Sci. Total Environ. 2018, 621, 201-209. [CrossRef] [PubMed]

41. Routledge, E.J.; Parker, J.; Odum, J.; Ashby, J.; Sumpter, J.P. Some alkyl hydroxy benzoate preservative (parabens) are estrogenic. Toxicol. Appl. Pharmacol. 1998, 153, 12-19, (cited in Soni et al. 2005). [CrossRef]

42. Okubo, T.; Yokoyama, Y.; Kano, K.; Kano, I. ER-dependent estrogenic activity of parabens assessed by proliferation of human breast cancer MCF-7 cells and expression of ERalpha and PR. Food Chem. Toxicol. 2001, 39, 1225-1232, (cited in Soni et al. 2005). [CrossRef]

43. Darbre, P.D.; Byford, J.R.; Shaw, L.E.; Horton, R.A.; Pope, G.S.; Sauer, M.J. Oestrogenic activity of isobutylparaben in vitro and in vivo. J. Appl. Toxicol. 2002, 22, 219-226, (cited in Soni et al. 2005). [CrossRef]

44. Darbre, P.D.; Byford, J.R.; Shaw, L.E.; Hall, S.; Coldham, N.G.; Pope, G.S. Oestrogenic activity of benzylparaben. J. Appl. Toxicol. 2003, 23, 43-51, (cited in Soni et al. 2005). [CrossRef]

45. Pugazhendhi, D.; Pope, G.S.; Darbre, P.D. Oestrogenic activity of p-hydroxybenzoic acid (common metabolite of paraben esters) and methylparaben in human breast cancer cell lines. J. Appl. Toxicol. 2005, 25, 301-309. [CrossRef]

46. McVay, L.V.; Sprunt, D.H. Moniliasis in aureomycin therapy. Soc. Exp. Biol. Med. 1951, 78, 759-761, (cited in Soni et al. 2005). [CrossRef]

47. Ritzau, M.; Swangsilpa, K. The prophylactic use of propylic ester of p-hydroxybenzoic acid on alveolitis sicca dolorosa. A preliminary report. Oral Surg. 1975, 43, 32-37, (cited in Soni et al. 2001). [CrossRef]

48. Metzger, W.I.; Wright, L.T.; Delorenzo, J.C. Effects of esters of parahydroxybenzoic acid on candida and yeast like fungi. J. Am. Med. Assoc. 1954, 155, 352-358, (cited in Soni et al. 2005). [CrossRef] 
49. Veien, N.K.; Hattel, T.; Laurberg, G. Oral challenge with parabens in paraben-sensitive patients. Contact Dermatitis 1996, 34, 433, (cited in Soni et al. 2002). [CrossRef]

50. George, N.D.; Srinivas, C.R.; Balachandran, C.; Shenoi, S.D. Sensitivity to various ingredients of topical preparations following prolonged use. Contact Dermat. 1990, 23, 367-368, (cited in Soni et al. 2002). [CrossRef]

51. Bajaj, A.K.; Chatterjee, A.K. Paraben contact hypersensitivity. Indian J. Dermatol. Venereol. Leprol. 1985, 51, 319-321, (cited in Soni et al. 2002).

52. Lindner, K.; Cramer, H.J.; Kohler, R. Allergic contact dermatitis caused by p-hydroxybenzoic acid in Varicosan\# bandage-A casuistic description. Dermatol. Mon. 1989, 175, 655-657, (cited in Soni et al. 2002).

53. Ibero, M.; Eseverri, J.L.; Barroso, C.; Botey, J. Dyes, preservatives and salicylates in the induction of food intolerance and/or hypersensitivity in children. Allergol. Immunopathol. 1982, 10, 263-268, (cited in Soni et al. 2005).

54. Antico, A.; Di Berardino, L. The role of additives in chronic pseudo-allergic dermatopathies from food intolerance. Allerg. Immunopathol. 1995, 27, 157-160, (cited in Soni et al. 2005).

55. Thune, P.; Granholt, A. Provocation tests with antiphlogistica and food additives in recurrent urticaria. Dermatologica 1975, 151, 360-367, (cited in Soni et al. 2005). [CrossRef]

56. Barr, L.; Metaxas, G.; Harbach, C.A.J.; Savoy, L.A.; Darbre, P.D. Measurement of paraben concentrations in human breast tissue at serial locations across the breast from axilla to sternum. J. Appl. Toxicol. 2012, 32, 219-232. [CrossRef] [PubMed]

57. McGrath, K.G. An earlier age of breast cancer diagnosis related to more frequent use of antiperspirants/deodorants and underarm shaving. Eur. J. Cancer Prev. 2003, 12, 479-485, (cited in Soni et al. 2005). [CrossRef]

58. Mirick, D.K.; Davis, S.; Thomas, D.B. Antiperspirant use and the risk of breast cancer. J. Natl. Cancer Inst. 2002, 94, 1578-1580, (cited in Tavares et al. 2009). [CrossRef] [PubMed]

59. Castelain, F.; Castelain, M. Parabens: A real hazard or a scare story? Eur. J. Dermatol. 2012, 22, 723-727. [CrossRef]

60. Khanna, S.; Darbre, P.D. Parabens enable suspension growth of MCF-10A immortalized, non-transformed human breast epithelial cells. J. Appl. Toxicol. 2013, 33, 378-382, (cited in Konduracka et al. 2014). [CrossRef]

61. Wróbel, A.; Gregoraszczuk, E.L. Effects of single and repeated in vitro exposure of three forms of parabens, methyl-, butyl- and propylparabens on the proliferation and estradiol secretion in MCF-7 and MCF-10A cells. Pharmacol. Rep. 2013, 65, 484-493, (cited in Konduracka et al. 2014). [CrossRef]

62. Konduracka, E.; Krzemieniecki, K.; Gajos, G. Relationship between everyday use cosmetics and female breast cancer. Polskie archiwum medycyny wewnetrznej 2014, 124, 264-269. [CrossRef]

63. Nishihama, Y.; Yoshinaga, J.; Iida, A.; Konishi, S.; Imai, H.; Yoneyama, M.; Nakajima, D.; Shiraishi, H. Association between paraben exposure and menstrual cycle in female university students in Japan. Reprod. Toxicol. 2016, 63, 107-113. [CrossRef] [PubMed]

64. Prusakiewicz, J.J.; Harville, H.M.; Zhang, Y.; Ackermann, C.; Voorman, R.L. Parabens inhibit human skin estrogen sulfotransferase activity: Possible link to paraben estrogenic effects. Toxicology 2007, 22, 248-256. [CrossRef]

65. Ellsworth, D.L.; Ellsworth, R.E.; Liebman, M.N.; Hooke, J.A.; Shriver, C.D. Genomic instability in histologically normal breast tissues: Implications for carcinogenesis. Lancet Oncol. 2004, 5, 753-758. [CrossRef]

66. Lengauer, C.; Kinzler, K.W.; Vogelstein, B. Genetic instabilities in human cancers. Nature 1998, 396, 643-649. [CrossRef]

67. Decker, A.H. Associations between Butylparaben and Thyroid Levels in Females Aged 12 and Over (NHANES, 2007-2008). Master's Thesis, Georgia State University, Atlanta, GA, USA, 2015.

68. Janjua, N.R.; Mortensen, G.K.; Andersson, A.; Kongshoj, B.; Skakkebaek, N.E.; Wulf, H.C. Systemic uptake of diethyl phthalate, dibutyl phthalate and butyl paraben following whole-body topical application and reproductive and thyroid hormone levels in humans. Environ. Sci. Technol. 2007, 41, 5564-5570. [CrossRef]

69. Ishiwatari, S.; Suzuki, T.; Hitomi, T.; Yoshino, T.; Matsukuma, S.; Tsuji, T. Effects of methyl paraben on skin keratinocytes. J. Appl. Toxicol. 2007, 27, 1-9. [CrossRef] [PubMed]

70. Towers, C.V.; Terry, P.D.; Lewis, D.; Howard, B.; Chamber, W.; Armistead, C.; Weitz, B.; Porter, S.; Borman, C.J.; Kennedy, R.C.M.; et al. Transplacental passage of antimicrobial paraben preservatives. J. Expo. Sci. Environ. Epidemiol. 2015, 25, 604-607. [CrossRef]

71. Jurewicz, J.; Radwan, M.; Wielgomas, B.; Dziewirska, E.; Karwacka, A.; Klimowska, A.; Kaluzny, P.; Radwan, P.; Bochenek, M.; Hanke, W. Human semen quality, sperm DNA damage, and the level of reproductive hormones in relation to urinary concentrations of parabens. J. Occup. Environ. Med. 2017, 59, 1034-1040. [CrossRef] [PubMed]

72. Guth, M.; Pollock, T.; Fisher, M.; Arbuckle, T.E.; Bouchard, M.F. Concentrations of urinary parabens and reproductive hormones in girls 6-17 years living in Canada. Int. J. Hygen Environ. Health 2021, 231, 113633. [CrossRef]

73. Arya, S.; Dwivedi, A.K.; Alvarado, L.; Kupesic-Plavsic, S. Exposure of U.S. population to endocrine disruptive chemicals (Parabens, Benzophenone-3, Bisphenol-A and Triclosan) and their associations with female infertility. Environ. Pollut. 2020, 265, 114763. [CrossRef]

74. Li, W.; Guo, J.; Wu, C.; Zhang, J.; Zhang, L.; Lv, S.; Lu, D.; Qi, X.; Feng, C.; Liang, W.; et al. Effects of prenatal exposure to five parabens on neonatal thyroid function and birth weight: Evidence from SMBCS study. Environ. Res. 2020, 188, 109710. [CrossRef]

75. Peng, X.; Yu, Y.; Tang, C.; Tan, J.; Huang, Q.; Wang, Z. Occurrence of steroid estrogens, endocrine-disrupting phenols, and acid pharmaceutical residues in urban riverine water of the Pearl River Delta, South China. Sci. Total Environ. 2008, 397, 158-166. [CrossRef] 
76. Gorga, M.; Petrovic, M.; Barceló, D. Multi-residue analytical method for the determination of endocrine disruptors and related compounds in river and wastewater using dual column liquid chromatography switching system coupled to mass spectrometry. J. Chromatogr. A 2013, 1295, 57-66. [CrossRef]

77. Brausch, J.M.; Rand, G.M. A review of personal care products in the aquatic environment: Environmental concentrations and toxicity. Chemosphere 2011, 88, 1518-1532. [CrossRef]

78. Sumpter, J.P. Endocrine disrupters in the aquatic environment: An overview. Acta Hydrochim. Hydrobiol. 2005, 33, 9-16, (cited in Renz et al. 2013). [CrossRef]

79. Renz, L.; Volz, C.; Michanowicz, D.; Ferrar, K.; Christian, C.; Lenzner, D.; El-Hefnawy, T. A study of parabens and bisphenol A in surface water and fish brain tissue from the Greater Pittsburgh Area. Ecotoxicology 2013, 22, 632-641. [CrossRef] [PubMed]

80. Kirschstein, R.L. Toxicology and carcinogenicity of preservatives used in the preparation of biological products. International Symposium on Preservatives in Biological Products, San Francisco. Dev. Biol. Stand. 1973, 24, 203-212, (cited in Soni et al. 2002).

81. Food and Drug Research Laboratories (FDRL). Teratologic Evaluation of FDA 71-38 (methyl paraben); US NTIS Report (PB-221785); Food and Drug Research Laboratories: Maspeth, NY, USA, 1972; 42p, (cited in Soni et al. 2002).

82. Food and Drug Research Laboratories (FDRL). Teratologic Evaluation of FDA 71-38 (methyl paraben); US NTIS Report (PB-223817); Food and Drug Research Laboratories: Maspeth, NY, USA, 1973; 14p, (cited in Soni et al. 2002).

83. Soehring, K.; Klingmuller, O.; Neuwald, F. Studies on the irritant action of some substances used as preservatives in ophthalmic solutions. Arzneim. Forsch. 1959, 9, 349-351. (In German)

84. Simonelli, M.; Marri, R. Toxicity and possible therapeutic application of the methyl ester of p-hydroxybenzoic acid. Bolletino Ital Biol. Sper. 1939, 14, 289-290, (cited in Soni et al. 2002).

85. Becquet, F.; Goldschild, M.; Moldovan, M.; Ettaiche, M.; Gastaud, P.; Boudouin, C. Histopathological effects of topical ophthalmic preservatives on rat corneoconjuctival surface. Curr. Eye Res. 1997, 17, 419-425, (cited in Soni et al. 2002). [CrossRef] [PubMed]

86. Sado, I. Synergistic toxicity of official permissible preservative food additives. Jpn. J. Hyg. 1973, 28, 463-476, (cited in Soni et al. 2001, 2005). [CrossRef]

87. Inai, K.; Aoki, Y.; Akamizu, H.; Eto, R.; Nishida, T.; Tokuoka, S. Tumorigenicity study of butyl and isobutyl p-hydroxybenzoates administered orally to mice. Food Chem. Toxicol. 1985, 23, 575-578, (cited in Soni et al. 2005). [CrossRef]

88. Hossaini, A.; Larsen, J.J.; Larsen, J.C. Lack of oestrogenic effects of food preservatives (parabens) in uterotrophic assays. Food Chem. Toxicol. 2000, 38, 319-323, (cited in Soni et al. 2005). [CrossRef]

89. Pedersen, K.L.; Pedersen, S.N.; Christiansen, L.B.; Korsgaard, B.; Bjerregaard, P. The preservatives ethyl-, propyl- and butylparaben are oestrogenic in an in vivo fish assay. Pharmacol. Toxicol. 2000, 86, 110-113, (cited in Soni et al. 2005). [CrossRef] [PubMed]

90. Oishi, S. Effects of propyl paraben on the male reproductive system. Food Chem. Toxicol. 2002, 40, 1807-1813. [CrossRef]

91. Hu, Y.; Zhang, Z.; Sun, L.; Zhu, D.; Liu, Q.; Jiao, J.; Li, J.; Qi, M. The estrogenic effects of benzylparaben at low doses based on uterotrophic assay in immature SD rats. Food Chem. Toxicol. 2013, 53, 69-74. [CrossRef]

92. Alam, M.S.; Ohsako, S.; Kanai, Y.; Kurohmaru, M. Single administration of butylparaben induces spermatogenic cell apoptosis in prepubertal rats. Acta Histochem. 2014, 116, 474-480. [CrossRef] [PubMed]

93. Hubbard, T.D.; Brix, A.; Blystone, C.R.; McIntyre, B.S.; Shockley, K.; Cunny, H.; Waidyanatha, S.; Turner, K.J.; McBride, S.; Roberts, G.K. Butylparaben multigenerational reproductive assessment by continuous breeding in Hsd:Sprague Dawley SD rats following dietary exposure. Reprod. Toxicol. 2020, 96, 258-272. [CrossRef]

94. Kim, M.J.; Kwack, S.J.; Lim, S.K.; Kim, Y.J.; Roh, T.H.; Choi, S.M.; Kim, H.S.; Lee, B.M. Toxicological evaluation of isopropylparaben and isobutylparaben mixture in Sprague-Dawley rats following 28 days of dermal exposure. Regul. Toxicol. Pharmacol. 2015, 73, 544-551. [CrossRef]

95. Maske, P.; Dighe, V.; Vanage, G. n-butylparaben exposure during perinatal period impairs fertility of the F1 generation female rats. Chemosphere 2014, 213, 114-123. [CrossRef] [PubMed]

96. Vo, T.T.B.; Yoo, Y.; Choi, K.; Jeung, E. Potential estrogenic effect(s) of parabens at the prepubertal stage of a postnatal female rat model. Reprod. Toxicol. 2010, 29, 306-316. [CrossRef]

97. Caon, T.; Costa, A.C.O.; Oliveira, M.A.L.; Micke, G.A.; Simões, C.M.O. Evaluation of the transdermal permeation of different paraben combination through a pig ear skin model. Int. J. Pharm. 2010, 391, 1-6. [CrossRef] [PubMed]

98. Dambal, V.Y.; Selvan, K.P.; Lite, C.; Barathi, S.; Santosh, W. Developmental toxicity and induction of vitellogenin in embryo-larval stages of zebrafish (Danio rerio) exposed to methyl paraben. Ecotoxicol. Environ. Saf. 2017, 141, 113-118. [CrossRef]

99. Lee, J.; Park, N.; Kho, Y.; Lee, K.; Ji, K. Phototoxicity and chronic toxicity of methyl paraben and 1,2-hexanediol in Daphnia magna. Ecotoxicology 2017, 26, 81-89. [CrossRef] [PubMed]

100. Terasaki, M.; Makino, M.; Tatarazako, N. Acute toxicity of parabens and their chlorinated by-products with Daphnia magna and Vibrio fischeri bioassays. J. Appl. Toxicol. 2008, 29, 242-247. [CrossRef]

101. Yamamoto, H.; Tamura, I.; Hirata, Y.; Kato, J.; Kagota, K.; Katsuki, S.; Yamamoto, A.; Kagami, Y.; Tatarazako, N. Aquatic toxicity and ecological risk assessment of seven parabens: Individual and additive approach. Sci. Total Environ. 2011, 401-411, 102-111. [CrossRef]

102. Schuebel, K. Toxicology of new preservatives: P-chlorobenzoic acid and p-hydroxybenzoic acid esters. Munch. Med. Wochenschr. 1930, 77, 13-14, (cited in Soni et al. 2001, 2002). 
103. Matthews, C.; Davidson, J.; Bauer, E.; Morrison, J.L.; Richardson, A.P. p-Hydroxybenzoic acid esters as preservatives. II. Acute and chronic toxicity in dogs, rats and mice. J. Am. Pharm. Assoc. Sci. 1956, 45, 260-267, (cited in Soni et al. 2001, 2002). [CrossRef] [PubMed]

104. Alder-Hradecky, C.; Kelentey, B. On the toxicity and local analgesic effects of p-hydroxybenzoic acid esters. Arch. Int. Pharmacodyn. Ther. 1960, 128, 135-142, (cited in Soni et al. 2001, 2002).

105. Litton Bionetics. Mutagenic Evaluation of Compound FDA 71-38, Methyl Paraben. US NTIS Report. PB245 459; 1974. Available online: https:/ /ntrl.ntis.gov/NTRL/dashboard/searchResults/titleDetail/PB245459.xhtml (accessed on 21 January 2021)(cited in Soni et al. 2002).

106. Council Directive (EEC) No 74/464 of 4 May 1976 on Pollution Caused by Certain Dangerous Substances Discharged into the Aquatic Environment of the Community. EUR-Lex-31976L0464-EN-EUR-Lex. Available online: europa.eu (accessed on 21 January 2021).

107. Council Directive (EEC) No 80/68 of 17 December 1979 on the Protection of Groundwater against Pollution Caused by Certain Dangerous Substances. EUR-Lex-31980L0068-EN-EUR-Lex. Available online: europa.eu (accessed on 21 January 2021).

108. Directive (EU) No 75/2010 of 24 November 2010 on Industrial Emissions (Integrated Pollution Prevention and Control). EURLex-32010L0075-EN-EUR-Lex. Available online: europa.eu (accessed on 21 January 2021).

109. Directive (EC) 2000/60 of 23 October 2000 of the European Parliament and of the Council Establishing a Framework for Community Action in the Field of Water Policy. EUR-Lex-32000L0060-EN-EUR-Lex. Available online: europa.eu (accessed on 21 January 2021).

110. Directive (EC) No 105/2008 of the European Parliament and of the Council of 16 December 2008 on Environmental Quality Standards in the Field of Water Policy, Amending and Subsequently Repealing Council Directives 82/176/EEC, 83/513/EEC, 84/156/EEC, 84/491/EEC, 86/280/EEC and Amending Directive 2000/60/EC of the European Parliament and of the Council. EUR-Lex-32008L0105-EN-EUR-Lex. Available online: europa.eu (accessed on 21 January 2021).

111. Directive (EU) No 39/2013 of 12 August 2013 on Priority Substances in the Field of Water Policy. EUR-Lex-32013L0039-EN-EURLex. Available online: europa.eu (accessed on 21 January 2021).

112. Council Directive (EEC) No 271/91 of 21 May 1991 Concerning Urban Wastewater Treatment. EUR-Lex-31991L0271-EN-EUR-Lex. Available online: europa.eu (accessed on 25 January 2021).

113. Sousa, J.C.G.; Ribeiro, A.R.; Barbosa, M.O.; Riveiro, C.; Tiritan, M.E.; Pereira, M.F.R.; Silva, A.M.T. Monitoring of the 17 EU Watch List contaminants of emerging concern in the Ave at the Sousa Rivers. Sci. Total Environ. 2019, 649, 1083-1095. [CrossRef] [PubMed]

114. Commission Implementing Decision (UE) No 495/2015 of 20 March 2015 Establishing a Watchlist of Substances for Union-wide Monitoring in the Field of Water Policy Pursuant to Directive 2008/105/EC of the European Parliament and of the Council. EUR-Lex-32015D0495-EN-EUR-Lex. Available online: europa.eu (accessed on 25 January 2021).

115. Commission Implementing Decision (EU) No 840/2018 of 5 June 2018 Establishing a Watch List of Substances for Union-Wide Monitoring in the Field of Water Policy Pursuant to Directive 2008/105/EC of the European Parliament and of the Council and Repealing Commission Implementing Decision (EU) 2015/495. EUR-Lex 32018D0840-EN-EUR-Lex. Available online: europa.eu (accessed on 21 January 2021).

116. Regulation (EC) No 1333/2008 of 16 December 2008 on Food Additives. EUR-Lex-32008R1333-EN-EUR-Lex. Available online: europa.eu (accessed on 21 January 2021).

117. Commission Regulation (EU) No 1129/2011 of 11 November 2011 Establishing a Union List of Food Additives. EUR-Lex32011R1129-EN-EUR-Lex. Available online: europa.eu (accessed on 25 January 2021).

118. Commission Regulation (EU) No 1130/2011 of 11 November 2011 Establishing a Union List of Food Additives Approved for Use in Food Additives, Food Enzymes, Food Flavourings and Nutrients. EUR-Lex-32011R1130-EN-EUR-Lex. Available online: europa.eu (accessed on 25 January 2021).

119. Commission Regulation (EU) No 231/2012 of 9 March 2012 Laying down Specifications for Food Additives Listed in Annexes II and III to Regulation (EC) No 1333/2008 of the European Parliament and of the Council. EUR-Lex-32012R0231-EN-EUR-Lex. Available online: europa.eu (accessed on 25 January 2021).

120. Regulation (EC) No 1223/2009 of the European Parliament and of the Council of 30 November of 2009 on Cosmetic Products. EUR-Lex-32009R1223 EN-EUR-Lex. Available online: europa.eu (accessed on 25 January 2021).

121. Commission Regulation (EU) No 358/2014 of 9 April 2014 Amending Annexes II and V to Regulation (EC) No 1223/2009 of the European Parliament and on the Council on Cosmetic Products. EUR-Lex-32014R0358-EN-EUR-Lex. Available online: europa.eu (accessed on 25 January 2021).

122. Commission Regulation (EU) No 1004/2014 of 18 September 2014 Amending Annex V to Regulation /EC) No 1223/2009 of the European Parliament and of the Council on Cosmetic Products. EUR-Lex-32014R1004-EN-EUR-Lex. Available online: europa.eu (accessed on 25 January 2021).

123. FDA-US Food and Drug Administration. Parabens in Cosmetics. 2021. Available online: https://www.fda.gov/cosmetics/ cosmetic-ingredients / parabens-cosmetics (accessed on 27 January 2021).

124. Cosmetics Design Europe. Inventory of Existing Cosmetic Ingredients in China (IECIC)—2015. China Cosmetic Regulations on Ingredients and Formulas. 2019. Available online: cosmeticsdesign-europe.com (accessed on 27 January 2021). 
125. Chemycal. Cosmetics-List of Regulated Ingredients in Cosmetic Products in China. Cosmetics I List of Regulated Ingredients in Cosmetic Products in China. 2018. Available online: chemycal.com (accessed on 27 January 2021).

126. Rastogi, S.C.; Schouten, A.; De Kruijf, N.; Weijland, J.W. Contents of methyl-, ethyl-, propyl-, butyl- and benzylparaben in cosmetic products. Contact Dermat. 1995, 32, 28-30, (cited in Soni et al. 2005). [CrossRef]

127. Guo, Y.; Wang, L.; Kannan, K. Phthalates and parabens in personal care products from China: Concentration and human exposure. Arch. Environ. Contam. Toxicol. 2014, 66, 113-119. [CrossRef] [PubMed]

128. Gao, C.; Kannan, K. Phthalates, bisphenols, parabens and triclocarban in feminine hygiene products from the United States and their implications for human exposure. Environ. Int. 2020, 136, 105465. [CrossRef]

129. Li, C.; Cui, X.; Chen, Y.; Liao, C. Paraben concentrations in human fingernail and its association with personal care product use. Ecotoxicol. Environ. Saf. 2020, 202, 110933. [CrossRef]

130. Kasprzyk-Hordern, B.; Dinsdale, R.M.; Guwy, A.J. The occurrence of pharmaceuticals, personal care products, endocrine disruptors and illicit drugs in surface water in South Wales, UK. Water Res. 2008, 42, 3498-3518. [CrossRef]

131. Bolz, U.; Hagenmaier, H.; Korner, W. Phenolic xenoestrogens in surface water, sediments, and sewage sludge from BadenWurttemberg, south-west Germany. Environ. Pollut. 2001, 115, 291-301. [CrossRef]

132. Jonkers, N.; Sousa, A.; Galante-Oliveira, S.; Barroso, C.M.; Kohler, H.E.; Giger, W. Occurrence and sources of selected phenolic endocrine disruptors in Ria de Aveiro, Portugal. Environ. Sci. Pollut. Res. 2010, 17, 834-843. [CrossRef] [PubMed]

133. Carmona, E.; Andreu, V.; Picó, Y. Occurrence of acidic pharmaceuticals and personal care products in Turia River Basin: From waste to drinking water. Sci. Total Environ. 2014, 484, 53-63. [CrossRef] [PubMed]

134. Li, W.; Shi, Y.; Gao, L.; Liu, J.; Cai, Y. Occurrence and human exposure of parabens and their chlorinated derivatives in swimming pools. Environ. Sci. Pollut. Res. 2015, 22, 17987-17997. [CrossRef]

135. González-Marino, I.; Quintana, J.B.; Rodríguez, I.; Cela, R. Simultaneous determination of parabens, triclosan and triclocarban in water by liquid chromatography/electronspray ionization tandem mass spectrometry. Rapid Commun. Mass Spectrom. 2009, 23, 1756-1766. [CrossRef] [PubMed]

136. Gibs, J.; Stackelberg, P.E.; Furlong, E.T.; Meyer, M.; Zaugg, S.D.; Lippincott, R.L. Persistence of pharmaceuticals and other organic compounds in chlorinated drinking water as a function of time. Sci. Total Environ. 2007, 373, 240-249. [CrossRef]

137. Blanco, E.; Casais, M.C.C.; Mejuto, M.C.; Cela, R. Combination of off-line solid-phase extraction and on-column sample stacking for sensitive determination of parabens and p-hydroxybenzoic acid in waters by non-aqueous capillary electrophoresis. Anal. Chim. Acta 2009, 647, 104-111. [CrossRef] [PubMed]

138. Casas Ferreira, A.M.; Möder, M.; Laespada, M.E.F. GC-MS determination of parabens, triclosan and methyl triclosan in water by in situ derivatisation and stir-bar sorptive extraction. Anal. Bioanal. Chem. 2011, 399, 945-953. [CrossRef] [PubMed]

139. Kasprzyk-Hordern, B.; Dinsdale, R.M.; Guwy, A.J. The removal of pharmaceuticals, personal care products, endocrine disruptors and illicit drugs during wastewater treatment and its impact on the quality of receiving waters. Water Res. 2009, 43, 363-380. [CrossRef]

140. Ma, W.; Zhao, X.; Zhang, Z.; Xu, T.; Zhu, F.; Li, Y. Concentrations and fate of parabens and their metabolites in two typical wastewater treatment plants in northeastern China. Sci. Total Environ. 2018, 644, 754-761. [CrossRef] [PubMed]

141. Kusk, K.O.; Krüger, T.; Long, M.; Taxvig, C.; Lykkesfeldt, A.E.; Frederiksen, H.; Andersson, A.; Andersen, H.R.; Hansen, K.M.S. Endocrine potency of wastewater: Contents of endocrine disrupting chemicals and effects measured by in vivo and in vitro assays. Environ. Toxicol. Chem. 2011, 30, 413-426. [CrossRef]

142. Wang, W.; Kannan, K. Fate of parabens and their metabolites in two wastewater treatment plants in New York State, Uniter States. Environ. Sci. Technol. 2016, 50, 1174-1181. [CrossRef]

143. Karthikraj, R.; Vasu, A.K.; Balakrishna, K.; Sinha, R.K.; Kannan, K. Occurrence and fate of parabens and their metabolites in five sewage treatment plants in India. Sci. Total Environ. 2017, 593-594, 592-598. [CrossRef]

144. Jonkers, N.; Kohler, H.E.; Dammshäuser, A.; Giger, W. Mass flows of endocrine disruptors in the Glatt River during varying weather conditions. Environ. Pollut. 2009, 157, 714-723. [CrossRef] [PubMed]

145. Terasaki, M.; Takemura, Y.; Makino, M. Paraben-chlorinated derivatives in river waters. Environ. Chem. Lett. 2012, 10, 401-406. [CrossRef]

146. Ramaswamy, B.R.; Shanmugam, G.; Velu, G.; Rengarajan, B.; Larsson, D.G.J. GC-MS analysis and ecotoxicological risk assessment of triclosan, carbamazepine and parabens in India rivers. J. Hazard. Mater. 2011, 186, 1586-1593. [CrossRef] [PubMed]

147. Czarczynska-Goslinska, B.; Zgola-Grzeskowiak, A.; Jeszka-Skowron, M.; Frankowski, R.; Grzeskowiak, T. Detection of bisphenol A, cumylphenol and parabens in surface waters of Greater Poland Voivodeship. J. Environ. Manag. 2017, 204, 50-60. [CrossRef] [PubMed]

148. Zgola-Grzeskowiak, A.; Jeszka-Skowron, M.; Czarczynska-Goslinska, B.; Grzeskowiak, T. Determination of parabens in polish river and lake water as a function of season. Anal. Lett. 2016, 49, 1734-1747. [CrossRef]

149. Galinaro, C.A.; Pereira, F.M.; Vieira, E.M. Determination of parabens in surface water from Mogi Guaçu River (São Paulo, Brazil) using dispersive liquid-liquid microextraction based on low density solvent and LC-DAD. J. Braz. Chem. Soc. 2015, 26, 2205-2213. [CrossRef]

150. Silveira, R.S.; Rocha, B.A.; Rodrigues, J.L.; Barbosa, F., Jr. Rapid, sensitive and simultaneous determination of 16 endocrinedisrupting chemicals (parabens, benzophenones, bisphenols, and triclocarban) in human urine based in microextraction by packed sorbent combined with liquid chromatography tandem mass spectrometry (MEPS-LC-MS/MS). Chemosphere 2020, $240,124951$. 
151. Guo, J.; Wu, C.; Lu, D.; Jiang, S.; Liang, W.; Chang, X.; Xu, H.; Wang, G.; Zhou, Z. Urinary paraben concentrations and their associations with anthropometric measures of children aged 3 years. Environ. Pollut. 2017, 222, 307-314. [CrossRef]

152. Wang, L.; Asimakopoulos, A.G.; Kannan, K. Accumulation of 19 environmental phenolic and xenobiotic heterocyclic aromatic compounds in human adipose tissue. Environ. Int. 2015, 78, 45-50. [CrossRef]

153. Ye, X.; Wong, L.; Jia, L.T.; Needham, L.L.; Calafat, A.M. Stability of the conjugated species of environmental phenols and parabens in human serum. Environ. Int. 2009, 35, 1160-1163. [CrossRef]

154. Van Overmeire, I.; Vrijens, K.; Nawrot, T.; Nieuwenhuyse, A.V.; Loco, J.V.; Reyns, T. Simultaneous determination of parabens, bisphenols and alkylphenols in human placenta by ultra-high performance liquid chromatography-tandem mass spectrometry. J. Chromatogr. B 2019, 1121, 96-102. [CrossRef]

155. Schlumpf, M.; Kypke, K.; Wittassek, M.; Angerer, J.; Mascher, H.; Mascher, D.; Vökt, C.; Birchler, M.; Lichtensteiger, W. Exposure patterns of UV filters, fragrances, parabens, phthalates, organochlor pesticides, PBDEs, and PCBs in human milk: Correlation of UV filters with the use of Cosmetics. Chemosphere 2010, 81, 1171-1183. [CrossRef]

156. Martín, J.; Santos, J.L.; Aparicio, I.; Alonso, E. Exposure assessment to parabens, bisfenol A and perfluoroalkyl compounds in children, women and men by hair analysis. Sci. Total Environ. 2019, 695, 133864. [CrossRef] [PubMed]

157. Heim, F. Die pharmakologisch-toxikologische PrÜfung von chemischen Zusatzsoffen zur Nahrung. Physik-Med./Soz Erlangen 1960, 81, 14-18, (cited in Soni et al. 2001).

158. Casas, L.; Fernández, M.F.; Llop, S.; Guxens, M.; Ballester, F.; Olea, N.; Irurzun, M.B.; Rodríguez, L.S.M.; Riaño, I.; Tardón, A.; et al. Urinary concentrations of phthalates and phenols in a population of Spanish pregnant women and children. Environ. Int. 2011, 37, 858-866. [CrossRef]

159. Kolatorova Sosvoroca, L.; Chlupacova, T.; Vitku, J.; Vlk, M.; Heracek, J.; Starka, L.; Saman, D.; Simkova, M.; Hampl, R. Determination of selected bisphenols, parabens and estrogens in human plasma using LC-MS/MS. Talanta 2017, 174, 21-28. [CrossRef]

160. Iribarne-Durán, L.M.; Domingo-Piñar, S.; Peinado, F.M.; Vela-Soria, F.; Jiménez-Díaz, I.; Barranco, E.; Olea, N.; Freire, C.; Artacho-Cordón, F.; Ocón-Hernández, O. Menstrual blood concentrations of parabens and benzophenones and related facts in a sample of Spanish women: An exploratory study. Environ. Res. 2020, 183, 109228. [CrossRef]

161. Zhang, H.; Quan, Q.; Li, X.; Sun, W.; Zhu, K.; Wang, X.; Sun, X.; Zhan, M.; Xu, W.; Lu, L.; et al. Occurrence of parabens and their metabolites in the paired urine and blood samples from Chinese university students: Implications on human exposure. Environ. Res. 2020, 183, 109288. [CrossRef] [PubMed]

162. Hines, E.P.; Mendola, P.; Von Ehrenstein, O.S.; Ye, X.; Calafat, A.M.; Fenton, S.E. Concentrations of environmental phenols and parabens in milk, urine and serum of lactating North Carolina women. Reprod. Toxicol. 2015, 54, 120-128. [CrossRef]

163. Tkalec, Z.; Kosjek, T.; Tratnik, J.S.; Stajnko, A.; Runkel, A.A.; Sykiotou, M.; Mazej, D.; Horvat, M. Exposure of Slovenian children and adolescents to bisphenols, parabens and triclosan: Urinary levels, exposure patterns, determinants of exposure and susceptibility. Environ. Int. 2021, 146, 106172. [CrossRef] [PubMed]

164. Jones, P.S.; Thigpen, D.; Morrison, J.L.; Richardson, A.P. p-Hydroxybenzoic acid esters as preservatives. III. The physiological disposition of p-hydroxybenzoic acid and its esters. J. Am. Pharm. Assoc. 1956, 45, 265-273, (cited in Soni et al. 2001, 2002, 2005). [CrossRef]

165. Tasukamoto, H.; Terada, S. Metabolismo of Drugs. XXIII. Metabolic fate of p-hydroxybenzoic acid and its derivatives in rabbits. Chem. Pharm. Bull. 1960, 8, 1066-1070, (cited in Soni et al. 2001). [CrossRef]

166. Tasukamoto, H.; Terada, S. Metabolismo of Drugs. XXVI. Metabolic fate of p-hydroxybenzoic acid and its derivatives in rabbits. Chem. Pharm. Bull. 1962, 10, 86-90, (cited in Soni et al. 2001). [CrossRef]

167. Tasukamoto, H.; Terada, S. Metabolismo of Drugs. XLVII. Metabolic fate of p-hydroxybenzoic acid and its derivatives in rabbits. Chem. Pharm. Bull. 1964, 12, 765-769, (cited in Soni et al. 2001, 2002, 2005). [CrossRef]

168. Derache, R.; Gourdon, J. Metabolism of a food preservative: P-hydroxybenzoic acid and its esters. Food Cosmet. Toxicol. 1963, 1, 189-195, (cited in Soni et al. 2001, 2002, 2005). [CrossRef]

169. Phillips, J.C.; Topp, C.S.; GAngolli, S.D. The metabolism of ethyl and n-propyl-p-hydroxybenzoate ("parabens") in male cats. Toxicol. Lett. 1978, 2, 237-242, (cited in Soni et al. 2001, 2005). [CrossRef]

170. Whitworth, C.W.; Jun, H.W. Influence of polysorbate 20 and sodium cholate on uptake of p-hydroxybenzoates by the frog, Rana pipiens. J. Pharm. Sci. 1973, 62, 1890-1891, (cited in Soni et al. 2001). [CrossRef]

171. Schuebel, K.; Manger, J. Contribution to the pharmacology of parahydroxybenzoic esters: The fate in the organism and toxicity. Arch. Exp. Pathol. Pharmacol. 1929, 146, 208-222, (cited in Soni et al. 2002).

172. Kim, J.; Ramaswamy, B.R.; Chang, K.; Isobe, T.; Tanabe, S. Multiresidue analytical method for the determination of antimicrobials, preservatives, benzotriazole UV stabilizers, flame retardants and plasticizers in fish using ultra high performance liquid chromatography coupled with tandem mass spectrometry. J. Chromatogr. A 2011, 1218, 3511-3520. [CrossRef]

173. Ramaswamy, B.R.; Kim, J.; Isobe, T.; Chang, K.; Amano, A.; Miller, T.W.; Siringan, F.P.; Tanabe, S. Determination of preservative and antimicrobial compounds in fish from Manila Bay, Philippines using ultra high performance liquid chromatography tandem mass spectrometry, and assessment of human dietary exposure. J. Hazard. Mater. 2011, 192, 1739-1745. [CrossRef] [PubMed]

174. Jakimska, A.; Huerta, B.; Barganska, Z.; Kot-Wasik, A.; Rodríguez-Mozaz, S.; Barceló, D. Development of a liquid chromatographytandem mass spectrometry procedure for determination of endocrine disrupting compounds in fish from Mediterranean rivers. J. Chromatogr. A 2013, 1306, 44-58. [CrossRef] 
175. Xue, J.; Sasaki, N.; Elangovan, M.; Diamond, G.; Kannan, K. Elevated accumulation of parabens and their metabolites in marine mammals from the United States coastal waters. Environ. Sci. Technol. 2015, 49, 12071-12079. [CrossRef] [PubMed]

176. Xue, J.; Kannan, K. Accumulation profiles of parabens and their metabolites in fish, black bear and birds, including bald eagles and albatrosses. Environ. Int. 2016, 94, 546-553. [CrossRef] [PubMed] 